\title{
In vitro screening and structural characterization of inhibitors of the SIOOB-p53 interaction
}

This article was published in the following Dove Press journal:

International Journal of High Throughput Screening

3 July 2010

Number of times this article has been viewed

\author{
Paul TWilder ${ }^{1,2}$ \\ Thomas H Charpentier' \\ Melissa A Liriano' \\ Kira Gianni' \\ Kristen MVarney' \\ Edwin Pozharski ${ }^{3}$ \\ Andrew Coop ${ }^{3}$ \\ Eric A Toth' \\ Alex D MacKerell ${ }^{3}$ \\ David J Weber ${ }^{1,2}$ \\ 'Department of Biochemistry and \\ Molecular Biology, The University \\ of Maryland School of Medicine, \\ ${ }^{2}$ HTS Center, University of Maryland \\ Greenebaum Cancer Center, \\ ${ }^{3}$ Department of Pharmaceutical \\ Sciences, The University of Maryland \\ School of Pharmacy, MD, USA
}

\begin{abstract}
S100B is highly over-expressed in many cancers, including malignant melanoma. In such cancers, S100B binds wild-type p53 in a calcium-dependent manner, sequestering it, and promoting its degradation, resulting in the loss of p53-dependent tumor suppression activities. Therefore, S100B inhibitors may be able to restore wild-type p53 levels in certain cancers and provide a useful therapeutic strategy. In this regard, an automated and sensitive fluorescence polarization competition assay (FPCA) was developed and optimized to screen rapidly for lead compounds that bind $\mathrm{Ca}^{2+}$-loaded $\mathrm{S} 100 \mathrm{~B}$ and inhibit $\mathrm{S} 100 \mathrm{~B}$ target complex formation. A screen of 2000 compounds led to the identification of 26 putative S100B low molecular weight inhibitors. The binding of these small molecules to S100B was confirmed by nuclear magnetic resonance spectroscopy, and additional structural information was provided by X-ray crystal structures of several compounds in complexes with S100B. Notably, many of the identified inhibitors function by chemically modifying Cys 84 in protein. These results validate the use of high-throughput FPCA to facilitate the identification of compounds that inhibit S100B. These lead compounds will be the subject of future optimization studies with the ultimate goal of developing a drug with therapeutic activity for the treatment of malignant melanoma and/or other cancers with elevated S100B.
\end{abstract}

Keywords: nuclear magnetic resonance, fluorescence polarization, melanoma, chlorpromazine, thimerosal, sanguinarine

\section{Introduction}

$\mathrm{S} 100 \mathrm{~B}$, a small $(21 \mathrm{kDa})$, dimeric, $\mathrm{Ca}^{2+-}$ and $\mathrm{Zn}^{2+}$-binding protein, is elevated in several types of cancer including reactive gliomas, renal cell tumors, malignant mature T-cells, and malignant melanoma, where its expression correlates inversely with patient survival. ${ }^{1-2}$ While aberrant expression of S100B has been used as a cancer marker in melanoma for over 20 years, more recent discoveries indicate that $\mathrm{S} 100 \mathrm{~B}$, and other S100 proteins (S100A1, S100A2, S100A4, S100A6), contribute to tumorigenesis by interacting with and downregulating the tumor suppressor protein, p53, and its homologs p63 and p73. ${ }^{3-14}$ Specifically, a decrease in transcription activation, as well as protein levels of ectopically expressed p53 and p53-regulated gene product, occurred in H1299 cells upon coexpression with S100B. ${ }^{5}$ The C8146A malignant melanoma cells express high levels of S100B that, when knocked down by the introduction of siRNA ${ }^{\mathrm{S} 100 \mathrm{~B}}$, result in a corresponding increase in wild-type p53 protein levels and its associated gene products. ${ }^{6}$ Cancer cells with elevated levels of S100B escape p53-dependent tumor suppression pathways even when the wild-type p53 genotype is intact because the S100B-p53 interaction downregulates p53 at the protein level.
Correspondence: David JWeber Department of Biochemistry and Molecular Biology, 108 North Greene Street, Baltimore, MD 2I20I, USA Tel +l 4107064354

Fax +l 4107060458

Email dweber@som.umaryland.edu 
In vitro, $\mathrm{S} 100 \mathrm{~B}$ was found to bind p53 directly, prevent its temperature-dependent oligomerization, and to inhibit protein kinase $\mathrm{C}$ (PKC)-dependent phosphorylation of the tumor suppressor. ${ }^{4}$ Therefore, a drug development program that disrupts the S100B-p53 interaction is underway as a means to restore functional p53 in cancers with elevated S100B, such as occurs in malignant melanoma that typically expresses wild-type $\mathrm{p} 53 .^{5-6}$

While many drugs target receptors, transporters, ion channels, and enzymes that have very discrete ligand binding sites, the development of small compounds that block the S100B-p53 interaction requires inhibition of larger protein-protein interfaces (PPIs) that were once thought to be difficult, if not impossible, to inhibit with small molecules. It is now recognized that the interfaces of most PPIs have smaller amino acid domain(s), termed "hot spots", that contribute more energetically to the PPIs than the surrounding protein surface. ${ }^{15}$ Successful strategies to target small molecule PPI inhibitors were developed and, as a result, several PPIs have been successfully blocked, including those involving bcl-2, p53, ERK, tubulin, and several SH2 domains, to name but a few. ${ }^{16-17}$ As with these proteins, a "hot spot" on $\mathrm{S} 100 \mathrm{~B}$ was recognized in structural studies with several different S100B-peptide complexes and small compounds. ${ }^{18,19}$

Taking advantage of existing atomic resolution structural information for $\mathrm{S} 100 \mathrm{~B}$ and its $\mathrm{Ca}^{2+}$-dependent target protein interactions (see Figure 1), a high-throughput screening (HTS) method was designed and implemented to identify rapidly and reliably compounds that bind the p53 binding site on $\mathrm{S} 100 \mathrm{~B}$ and inhibit their complex formation. A peptide derived from the C-terminus of p53 residues 367-388 (p53 $367-388$ ) was found to bind $\mathrm{S} 100 \mathrm{~B}$ in a $\mathrm{Ca}^{2+}$-dependent manner, inhibiting the PKC-dependent phosphorylation of the peptide in a manner identical to what is seen for full length $\mathrm{p} 53 .{ }^{20-21}$ Therefore, the three-dimensional structure of this peptide bound to $\mathrm{Ca}^{2+}$ S100B was determined using nuclear magnetic resonance (NMR) spectroscopic methods, revealing that a hydrophobic cleft exposed upon $\mathrm{Ca}^{2+}$ binding to $\mathrm{S} 100 \mathrm{~B}$ is necessary for binding $\mathrm{p} 53 .^{20,22,23}$ Several other peptides and small molecules have been shown to interact with this hydrophobic pocket on $\mathrm{S} 100 \mathrm{~B}$, in particular a small 12-residue peptide, TRTK-12, that was sufficient for inhibiting complex formation between S100B and full-length p53. ${ }^{18,19}$ The NMR solution and X-ray crystal structure TRTK-12 bound to S100B confirms that it binds in the same hydrophobic pocket on S100B as does p53 (see Figure 1B). ${ }^{24,25}$ With this in mind, an in vitro fluorescence polarization competition assay (FPCA) using an N-terminal 5-carboxytetramethylrhodamine (TAMRA)-labeled version of the TRTK-12 peptide (TAMRA-TRTK) was developed to screen for inhibitors that target this discrete hydrophobic pocket on $\mathrm{Ca}^{2+}$-loaded S100B.

Fluorescent polarization assays have been increasingly used in HTS due to their generally good sensitivity, rapid response, homogeneous format (no separation steps needed), and simple instrumentation, as reviewed by Huang and Aulabaugh. ${ }^{26}$ The principle of fluorescence polarization is well suited to studying the interaction of molecules
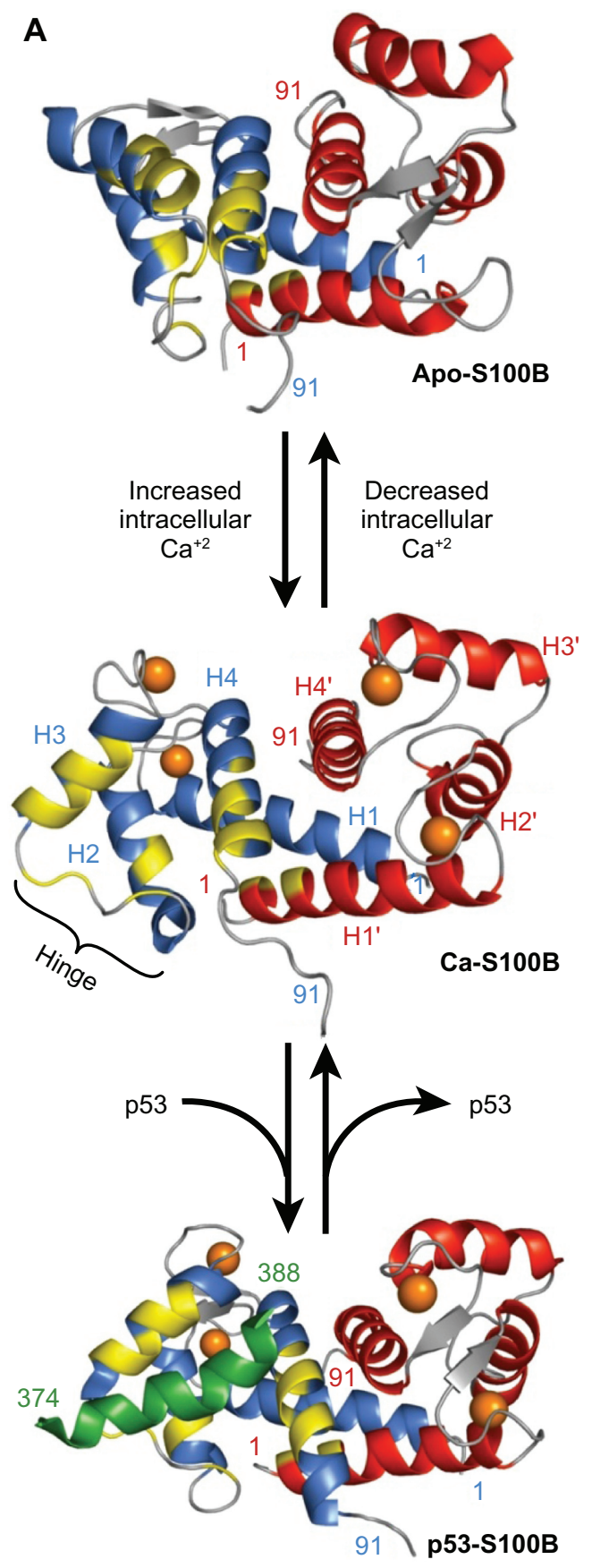




Figure I The calcium-dependent interaction of $\mathrm{SIOOB}$ with $\mathrm{p} 53$. (A) The solution structures of, from top to bottom, apo-SI00B (PDB ISYM), Ca-SI00B (PDB IQLK), and $\mathrm{p} 53-\mathrm{Ca}-\mathrm{SIOOB}$ (PDB IDT7) reveal a large conformational change in SI00B upon binding $\mathrm{Ca}^{2+}$, exposing a hydrophobic cleft that is capable of binding the tumor suppressor p53.22,28,58 One monomer of the dimeric SI0OB is shown in blue and the other in red with yellow residues, highlighting amino acids known to interact with the $p 53^{367-388}$ peptide. The structured region of the $\mathrm{p} 53^{367-388}$ peptide formed by residues 374-388, shown in green, binds to the hydrophobic cleft between helix 3 $(\mathrm{H} 3)$ and $4(\mathrm{H} 4)$ of the $\mathrm{Ca}^{2+}$-bound protein, thus connecting $\mathrm{Ca}^{2+}$-signaling pathways with $p 53$. There are actually two identical $p 53$ binding sites on SI00B but only one is shown occupied. (B) A close-up of helix $3(\mathrm{H} 3)$ and $4(\mathrm{H} 4)$ have been aligned with the same region in the TRTK-I 2 bound $\mathrm{Ca}-\mathrm{SIOOB}$ structure (PDB IMWN) show that the $\mathrm{p} 53$ peptide (green) and the TRTK- 12 peptide (red) bind the same site but with slightly different orientations. ${ }^{24}$ In addition, the large hydrophobic Trp in TRTK12 buries itself deeper in the core of SIOOB than the smaller, but homologous, Leu in the $\mathrm{p}^{53^{367-388}}$ peptide. ${ }^{18,24}$

Abbreviation: NMR, nculear magentic resonance.

with significantly different molecular weights, such as the S100B at $10.7 \mathrm{kDa}$ and the TRTK-12 peptide at $1.5 \mathrm{kDa}$ used here. The smaller probe is labeled with a fluorophore and then exposed to polarized light, leading to excitation of only those molecules in the correct orientation. The fluorescence emission is measured parallel and perpendicular to the excitation source, allowing the degree of polarization to be determined. The larger, slower, tumbling molecules will retain a higher degree of polarization, such as when the peptide probe is bound to the larger S100B, while the smaller faster-moving unbound probe will have a lower polarization. In our FPCA assay, the probe will be displaced, or competed off, by small molecules decreasing the fluorescence polarization (Figure 2).

The high-throughput FPCA developed was used to screen the 2000-compound Spectrum Collection comprised of known drugs and biologically active compounds, and revealed several compounds that inhibit the TRTK-S100B interaction. NMR spectroscopic methods confirm that the compounds bind S100B, and X-ray crystal structures have been determined for three of the compounds from the library. Structures of chlorpromazine (SC0067), thimerosal (SC0322), and sanguinarine (SC0844) bound to S100B indicate that all three molecules have the same hydrophobic cleft of $\mathrm{Ca}^{2+}$-loaded S100B. Two of the structures reveal that the compounds covalently modify Cys 84 in S100B, and further studies confirm that many of the inhibitors found in this screen may function in a similar mannner.

\section{Material and methods Materials}

All chemical reagents were American Chemical Society grade or higher unless otherwise indicated. All buffers were passed through Chelex-100 (Bio-Rad, Hercules, CA) to
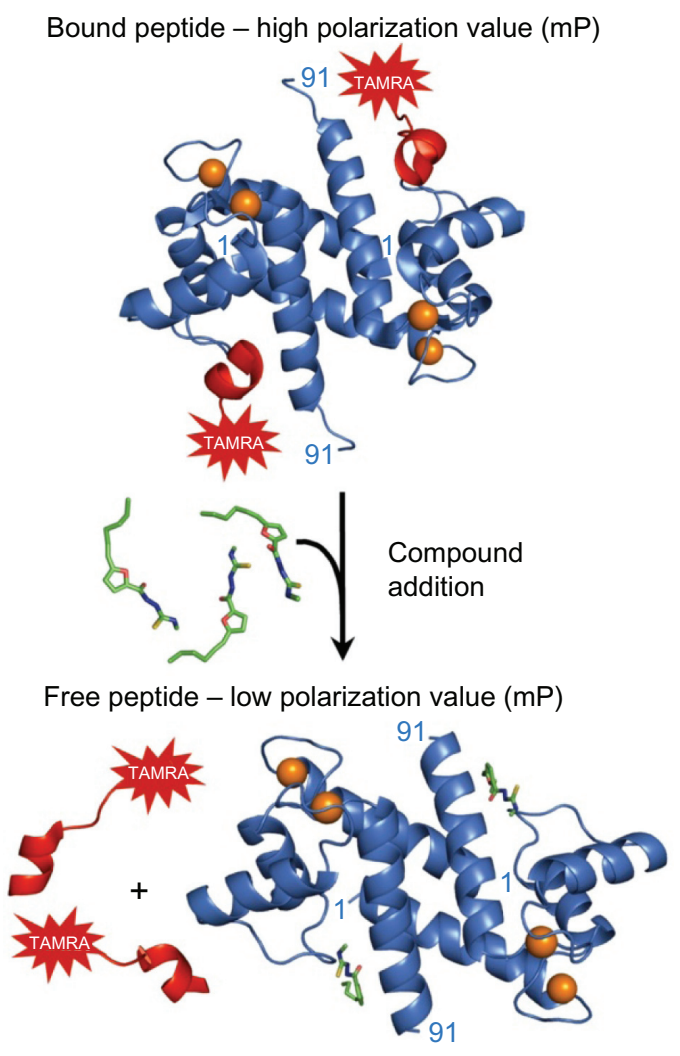

Figure 2 Schematic illustrating the FPCA. The FPCA uses the change in polarization of a TAMRA-labeled peptide derived from residues 265-276 of the actin capping protein CapZ (TAMRA-TRTK) that binds to SI00B in the same region as $\mathrm{p} 53$ peptide (see Figure I). In the presence of calcium, SIOOB binds TAMRA-TRTK causing the peptide to rotate slower, and the polarization values to increase. The addition of compounds that bind the same region displace the peptide, allowing it to rotate freely and decreasing the polarization value. A HTS version of this assay was used to screen for putative inhibitors of $\mathrm{SIOOB}$, and it is also used to determine the binding affinity $\left(K_{D}\right)$ of the compound to SIOOB (see Table 2). The SIOOB dimer is shown in blue, the TAMRA-TRTK in red, and the $\mathrm{Ca}^{2+}$ ions are shown as orange spheres. Abbreviations: FPCA, fluorescence polarization competition assay; HTS, highthroughput screening. 
remove trace metals. The $\mathrm{D}_{2} \mathrm{O}, \mathrm{D}_{6}-\mathrm{DMSO},{ }^{15} \mathrm{NH}_{4} \mathrm{Cl}$, and ${ }^{13}$ $\mathrm{C}$-labeled glucose were purchased from Cambridge Isotope Laboratories, Inc. (Andover, MA). The 2000-compound Spectrum Collection of known drugs and natural products were purchased from MicroSource Discovery Systems Inc. (Gaylordsville, CT) and suspended in $100 \%$ DMSO or $\mathrm{D}_{6}$-DMSO for NMR experiments. All other chemicals and small compounds screened were purchased from LKT (St. Paul, MN), Sigma-Aldrich (St. Louis, MO), Calbiochem (San Diego, CA), or Chembridge (San Diego, CA).

\section{Preparation of recombinant SIOOB}

The pET1 $1 b$ expression vector (Novagen Inc., Madison, WI) containing either rat S100B gene, a double-mutant (C68/84S) rat S100B gene, or the bovine S100B gene (for crystallization) was used for the production of the S100B in HMS174 (DE3) cells (Novagen Inc., Madison, WI). ${ }^{27}$ Mammalian S100B is highly conserved, rat is $95.6 \%$ homologous to bovine, with rat M7, E62, S78, and V80 being V7, S62, A78, and I80, respectively, in bovine S100B. Unlabeled and ${ }^{15} \mathrm{~N}$-labeled S100B were prepared and purified (>99\%) under reducing conditions using procedures similar to those described previously, ${ }^{27,28}$ except that dithiothreitol (DTT) was used as a reducing agent instead of $\beta$-mercaptoethanol. The concentrations of S100B stock solutions were determined using the Bio-Rad Protein Assay (Bio-Rad Inc., Hercules, CA) using wild-type S100B of known concentration as the standard. The concentration of this S100B standard was determined by quantitative amino acid analysis (BioSynthesis Inc., Lewisville, TX). The S100B was stored at a concentration of $\sim 10 \mathrm{mM}$ in $<2 \mathrm{mM}$ TES or HEPES, at $\mathrm{pH} 7.2$, with $0.5 \mathrm{mM}$ DTT at $-20^{\circ} \mathrm{C}$ until use.

\section{Peptides}

All peptides were synthesized using solid-state peptide synthesis and their purity was determined to be $>95 \%$ by high pressure liquid chromatography and mass spectrometry (Biosynthesis Inc., Lewisville, TX). The p53 peptides were derived from the terminal 27 residues of human $\mathrm{p} 53$, residues 367-393 (SHLKSKKGQSTSRHKKLMFKTEGPDSD), either with the $\mathrm{N}$-terminus acetylated ( $\left.\mathrm{p} 53^{367-393}\right)$, fluorescein isothiocyanate (FITC)-labeled (FITC-p53 $3^{367-393}$ ), or TAMRA-labeled (TAMRA-p53 $3^{367-393}$ ). The TRTK-12 peptides are derived from the CapZ protein residues 265-276 (TRTKIDWNKILS), the C-termini are amidated, and have either the N-terminus acetylated (TRTK) or TAMRA-labeled (TAMRA-TRTK). The Hdm4 peptides derived from the human homolog of Mdm4 residues 25-43 (QINQVRPKLPLLKILHAAGAQ) have the C-termini amidated, and have either the $\mathrm{N}$-terminus acetylated ( $\left.\mathrm{Mdm} 4^{25-43}\right)$ or TAMRA-labeled (TAMRA-Mdm4 ${ }^{25-43}$ ). Each peptide was soluble and stored in $\mathrm{H}_{2} \mathrm{O}$ at $\mathrm{pH}$ 7.2. The concentration of the stock solutions of unlabeled peptides were determined by quantitative amino acid analysis (Biosynthesis Inc., Lewisville, TX) and/or determined using the extinction coefficient for the methyl ester of $\mathrm{N}$-acetyl tryptophan, $\varepsilon_{280}=5600 \mathrm{~cm}^{-1} \mathrm{M}^{-1}$, as previously described..$^{20}$ The concentration of FITC peptides was determined at $\mathrm{pH} 8.0$ using the extinction coefficient for amide-linked FITC, $\varepsilon_{494}=68,000$ $\mathrm{cm}^{-1} \mathrm{M}^{-1}$, and the TAMRA peptides by using the extinction coefficient for TAMRA, $\varepsilon_{547}=65,000 \mathrm{~cm}^{-1} \mathrm{M}^{-1} \cdot{ }^{29}$

\section{Fluorescent polarization competition assay}

Fluorescence polarization experiments were performed in Corning 96-well, flat bottom, black assay plates (Corning, NY) in a final volume of $200 \mu \mathrm{L}$. The final assay buffer used in the screens contained $2.5 \mu \mathrm{M}$ rat S100B (or $5 \mu \mathrm{M}$ C68/84S mutant rat S100B), $50 \mathrm{nM}$ TAMRA-TRTK, $50 \mathrm{mM}$ TES or HEPES, pH 7.2, $15 \mathrm{mM} \mathrm{NaCl}, 100 \mathrm{mM}$ $\mathrm{KCl}, 10 \mathrm{mM} \mathrm{CaCl}_{2}, 0.10 \%$ Triton X-100, and 5\% DMSO. Automation of the liquid handling and compound addition was performed using either an eight-span pipetting head-equipped Biomek NX, or a 96-well pipetting headequipped Biomek FX laboratory automation workstation (Beckman-Coulter). Increasing amounts of S100B were added to determine the affinity of S100B for the peptide in these buffer conditions. The high throughput FPCA was performed at four different concentrations of compound, ie, $62.5,31.3,15.6$, and $7.8 \mu \mathrm{M}$ that, with the "no S100B" control and the "no inhibitor" control, could be used to estimate the $\mathrm{IC}_{50}$. More robust titrations of the "hits" from the high throughput FPCA were performed to determine more accurate $\mathrm{IC}_{50}$ values for the compounds under the same conditions. All solutions used in the FPCA were incubated for a minimum of 15 minutes at $37^{\circ} \mathrm{C}$, at which time the polarization was read at $37^{\circ} \mathrm{C}$ from the top of the well with a BMG POLARstar fluorescent plate reader (BMG Labtech, Durham, NC) using a $544 \pm 5 \mathrm{~nm}$ excitation and $590 \pm 15 \mathrm{~nm}$ emission filter.

The quality and suitability of the high-throughput FPCA were evaluated using the $\mathrm{Z}$ factor developed by Zhang et al. ${ }^{30}$ The $\mathrm{Z}$ factor $=1-\left(3 \mathrm{SD}_{\mathrm{b}}+3 \mathrm{SD}_{\mathrm{f}}\right) /\left(\mu_{\mathrm{b}}-\mu_{\mathrm{f}}\right)$, where $\mu_{\mathrm{b}}$ and $\mu_{\mathrm{f}}$ are the mean polarization (mP) values of 
the bound and free probe, respectively, and $\mathrm{SD}_{\mathrm{b}}$ and $\mathrm{SD}_{\mathrm{f}}$ are the standard deviations of those values for bound and free probe, respectively. The $\mathrm{Z}$ factor can be any value $\leq 1$, with a value of 1 being an ideal assay, $\geq 0.5$ but $<1.0$ being an excellent assay, and a value $<0.5$ being unacceptable for our application.

The binding data were fit using a single-site binding model with Origin software (OriginLab Corp., Northampton, MA), with one peptide bound per symmetrical S100B subunit. For the fluorescence polarization competition titrations, an equation derived by Nikolovska-Coleska et al was used to calculate the $\mathrm{K}_{\mathrm{D}}$ from $\mathrm{IC}_{50}$ titrations as follows: $\mathrm{K}_{\mathrm{D}}=[\mathrm{I}]_{50} /\left([\mathrm{L}]_{50} /{ }^{\text {TAMRA-TRTK }} \mathrm{K}_{\mathrm{D}}+[\mathrm{P}]_{0} /{ }^{\text {TAMRA-TRTK }} \mathrm{K}_{\mathrm{D}}+1\right)$ where $[\mathrm{I}]_{50}$ is the concentration of the unlabeled compound at $50 \%$ inhibition, $[\mathrm{L}]_{50}$ is the concentration of the free TAMRA-TRTK at $50 \%$ inhibition, $[\mathrm{P}]_{0}$ is the concentration of the free protein at $0 \%$ inhibition, and ${ }^{\text {TAMRA-TRTK }} \mathrm{K}_{\mathrm{D}}$ is the dissociation constant of the S100B-TAMRA-TRTK complex $\left({ }^{\text {TAMRA-TRTK }} K_{\mathrm{D}}=1.19 \pm 0.65 \mu \mathrm{M}\right.$; see Figure 3$){ }^{31}$

\section{Fluorescence polarization binding assay}

The same buffer conditions as for the FPCA were used when determining the affinity of the different peptides for rat $\mathrm{S} 100 \mathrm{~B}$ or the $\mathrm{C} 68 / 84 \mathrm{~S}$ mutant rat $\mathrm{S} 100 \mathrm{~B}$, except that an increasing concentration of S100B protein was added while monitoring the change in polarization at $544 \pm 10 \mathrm{~nm}$ excitation and $590 \pm 10 \mathrm{~nm}$ emission filter for TAMRA-labeled peptides and $485 \pm 10 \mathrm{~nm}$ excitation and $520 \pm 10 \mathrm{~nm}$ emission filter for the FITC-labeled peptide. All measurements were performed on a Varian Carey Eclipse fluorescence spectrophotometer with a control temperature cell at $37^{\circ} \mathrm{C}$ in a $3 \times 3 \mathrm{~mm}$ cuvette. The binding data were fitted using a single-site binding model with Origin software (OriginLab Corp., Northampton, MA), with one peptide bound per symmetrical S100B subunit.

\section{Nuclear magnetic resonance spectroscopy}

NMR spectra were collected at $37^{\circ} \mathrm{C}$ with either a Bruker DMX600 NMR spectrometer (600.13 MHz for protons) or a Bruker AVANCE 800 NMR spectrometer $(800.27 \mathrm{MHz}$ for protons) equipped with pulsed-field gradients, four frequency channels, and triple resonance, z-axis gradient cryogenic probes. A one-second relaxation delay was used, and quadrature detection in the indirect dimensions was obtained with states-TPPI phase cycling; initial delays in the indirect dimensions were set to give zero- and first-order


Figure 3 Data from the FPCA assay. (A) The binding of SI00B to TAMRA-TRTK was measured in the FPCA buffer conditions giving a $K_{D}=1.19 \pm 0.65 \mu \mathrm{M}$. (B) The $Z$ factor of $0.7 \mathrm{I}$ within the acceptable range of 0.5 to 1.0 was determined for the FPCA assay with $2.5 \mu \mathrm{M}$ SIOOB and $50 \mathrm{nM}$ TAMRA-TRTK (see Materials and methods section for equation)..$^{30}$ (C) The HTS FPCA was run on four different concentrations of compounds; shown is the resulting percentage inhibition from the $62.5 \mu \mathrm{M}$ concentration for each compound. Any compounds inhibiting greater than two standard deviations from the mean, shown with the dashed line, were tested by NMR to confirm that they bound SIOOB for each compound concentration, resulting in 26 inhibitors (see Table 2). There were some compounds that appeared to increase the binding, two standard deviations below the average; however, none of these compounds bound $\mathrm{SIOOB}$, with the false signal caused by FI in the FPCA. Abbreviations: FPCA, fluorescence polarization competition assay; NMR, nuclear magnetic resonance; FI, fluorescence interference; HTS, high-throughput screening. 
<smiles>CN1CCc2cccc3c2[C@H]1Cc1ccc(O)c(O)c1-3</smiles><smiles>CN(C)CCCN1c2ccccc2Sc2ccc(Cl)cc21</smiles><smiles>CCSc1ccccc1C(=O)O</smiles><smiles>CN1CCN(CCCN2c3ccccc3Sc3ccc(C(F)(F)F)cc32)CC1</smiles><smiles>CC(=O)O[Hg]c1ccccc1</smiles><smiles>Cc1c(OCC(F)(F)F)ccnc1CS(=O)c1nc2ccccc2[nH]1</smiles><smiles>COC(=O)[C@]1(C)CC[C@]2(C)CC[C@@]3(C)C4=CC(=O)C(O)=C(C)C4=CC=C3[C@]2(C)CC1</smiles><smiles>O=C1C(Cl)=C(Cl)C(=O)C(Cl)=C1Cl</smiles><smiles>C=CC(C1=CC(=O)C=CC1=O)c1ccccc1</smiles>

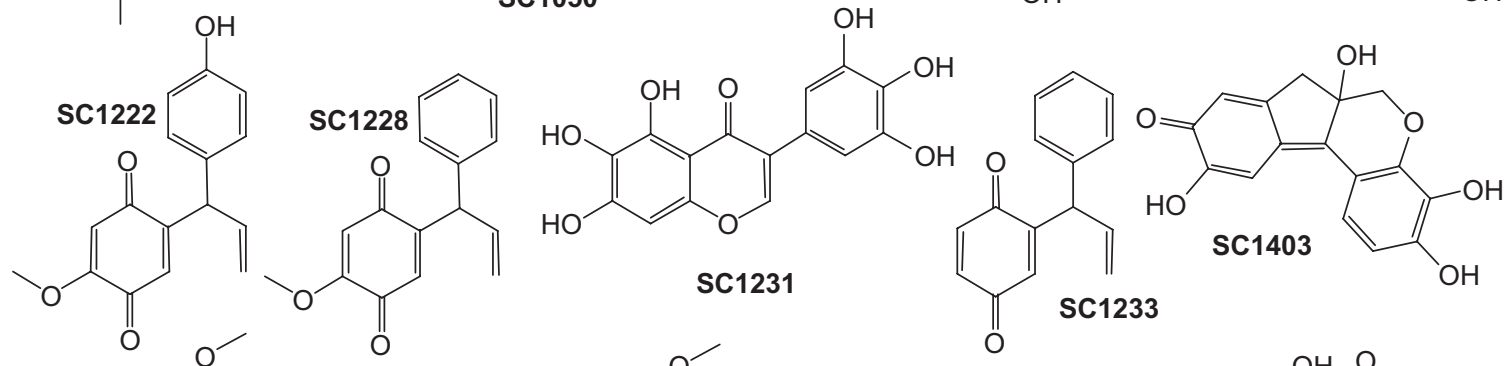

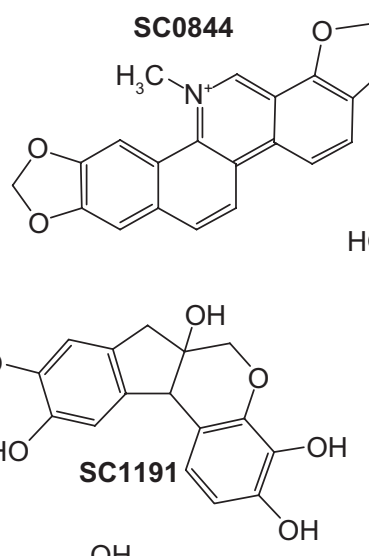

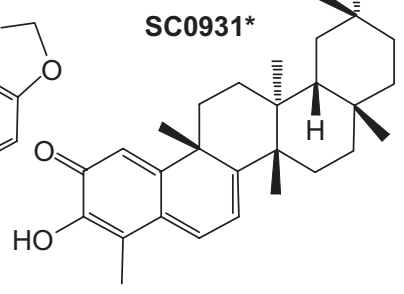<smiles>Oc1ccc2c(c1)OCC1(O)Cc3cc(O)c(O)cc3C21</smiles><smiles>C=CC(C1=CC(=O)C(OC)=CC1=O)c1ccc(OC)cc1</smiles><smiles>C=C[C@H](C1=CC(=O)C(OC)=C(OC)C1=O)c1ccccc1</smiles><smiles>COC1=CC(=O)C(O)=C/C1=C\C=C\C=C\c1ccccc1</smiles><smiles>CC1=CC(=O)c2c(C)cccc2C(=O)C1(O)C(=O)O</smiles><smiles>O=C1C(Cl)=C(Cl)C(=O)c2c(O)ccc(O)c21</smiles>

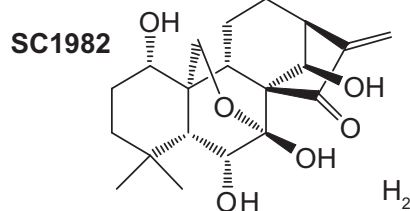<smiles></smiles>

Figure 4 Molecular structures of the SIOOB inhibitors. The chemical structures of the 26 compounds confirmed to bind SIO0B (see Table 2) are illustrated with an asterisk, indicating that those compounds bound the cysteine-free SIO0B mutant, C68/84S. The inhibition mechanism of the other compounds involves the modification of cysteines in SIOOB.

phase corrections of $90^{\circ}$ and $-180^{\circ}$, respectively. ${ }^{32,33}$ Data were processed using the processing program nmrPipe on Linux workstations..$^{34}$ All proton chemical shifts are reported with respect to the $\mathrm{H}_{2} \mathrm{O}$ or $\mathrm{HDO}$ signal, taken to be $4.658 \mathrm{ppm}$ relative to external TSP $(0.0 \mathrm{ppm})$ at $37^{\circ} \mathrm{C}$. The ${ }^{15} \mathrm{~N}$ chemical shifts were indirectly referenced using the zero-point frequency at $37^{\circ} \mathrm{C}$ of 0.10132905 for ${ }^{15} \mathrm{~N}^{-1} \mathrm{H}$, as previously described. ${ }^{35-37}$
Uniformly ${ }^{15} \mathrm{~N}$-labeled S100B was used to collect two-dimensional heteronuclear single quantum coherence (HSQC) spectra of S100B-compound complexes. Specifically, the ${ }^{1} \mathrm{H},{ }^{15} \mathrm{~N}$-fast HSQC experiment was collected for each point in titrations of $\mathrm{Ca}^{2+}$-loaded S100B with various compounds to monitor changes in the backbone ${ }^{15} \mathrm{~N}$ and ${ }^{1} \mathrm{H}$ resonances of S100B ${ }^{38}$ Typical NMR samples contained 0.05-0.50 mM rat S100B (or C68/84S rat S100B), 0-5.0 mM 
compound, $10 \mathrm{mM}$ TES or $10 \mathrm{mM}$ HEPES, pH 7.2, $15 \mathrm{mM}$ $\mathrm{NaCl}, 10 \mathrm{mM} \mathrm{CaCl}_{2}, 0.34 \mathrm{mM} \mathrm{NaN}_{3}, 5-10 \% \mathrm{D}_{2} \mathrm{O}$, and $0-5 \%$ $\mathrm{D}_{6}$-DMSO.

Group epitope mapping via saturation transfer difference (STD) NMR was completed for the chlorpromazine-S100B complex in a manner similar to that described previously. ${ }^{39}$ Specifically, during the two-second presaturation pulse, the on-resonance irradiation of the protein was performed at a chemical shift of $-0.4 \mathrm{ppm}$ and the off-resonance irradiation was applied at $30 \mathrm{ppm}$, where no protein signals were present. As a control, the STD experiments were collected in the absence of a $T_{1 \rho}$ filter, and as expected, the onedimensional spectrum of holo-S100B was fully restored. The final sample contained $50 \mu \mathrm{M} \mathrm{S100B}, 1.0 \mathrm{mM} \mathrm{SC0067,}$ $10 \mathrm{mM} \mathrm{CaCl}_{2}, 5 \% \mathrm{D}_{6}$-DMSO, 99.98\% D 2 O, $15 \mathrm{mM} \mathrm{NaCl}$, $0.34 \mathrm{mM} \mathrm{NaN}_{3}$, and $10 \mathrm{mM}$ Tris $\mathrm{D}_{11}$, at $\mathrm{pH}$ 7.2. The STD data were collected at $25^{\circ} \mathrm{C}$ to achieve more efficient saturation of the protein. Proton assignments of chlorpromazine were confirmed in the above conditions in the absence and presence of S100B using two-dimensional total correlation spectroscopy experiments. ${ }^{40}$

\section{Protein crystallization}

Diffraction quality crystals for the chlorpromazine- $\mathrm{Ca}^{2+}$ S100B complex were obtained via sitting drop vapor diffusion at $22^{\circ} \mathrm{C}$ by mixing $2 \mu \mathrm{L}$ of $\mathrm{S} 100 \mathrm{~B}$ protein $(40 \mathrm{mg} /$ $\mathrm{mL} \mathrm{S100B,} 7.5 \mathrm{mM} \mathrm{CaCl}_{2}, 4.0 \mathrm{mM} \mathrm{SC0067,} 20 \mathrm{mM}$ cacodylate buffer at $\mathrm{pH} 7.2$ ) with a $2 \mu \mathrm{L}$ of reservoir solution (200 $\mathrm{mM} \mathrm{CaCl}_{2}, 0.1 \mathrm{M}$ Bis-Tris buffer at $\mathrm{pH} 7.0$, and $42 \%$ MPD) and equilibrating for 30-60 days. After crystals formed, they were cryoprotected in a harvest solution (200 $\mathrm{mM} \mathrm{CaCl}_{2}, 4.0 \mathrm{mM}$ chlorpromazine, $0.1 \mathrm{M}$ Bis-Tris buffer at pH 7.0, 45\% MPD, and 5\% glycerol) for 30-60 seconds and then flash-cooled in liquid nitrogen. The SC0332-Ca ${ }^{2+}-\mathrm{S} 100 \mathrm{~B}$ (2-3 day crystal formation) and SC0844-Ca ${ }^{2+}-\mathrm{S} 100 \mathrm{~B}$ (15-30 day crystal formation) complexes were crystallized in a similar manner using complex-specific protein buffers (SC0332-Ca ${ }^{2+}-\mathrm{S} 100 \mathrm{~B}$, $40 \mathrm{mg} / \mathrm{mL} \mathrm{S} 100 \mathrm{~B}, 15 \mathrm{mM} \mathrm{CaCl}, 4.0 \mathrm{mM} \mathrm{SC0332}$, and $20 \mathrm{mM}$ cacodylate buffer at $\mathrm{pH}$ 7.2; $\mathrm{SC} 0844-\mathrm{Ca}^{2+}-\mathrm{S} 100 \mathrm{~B}$,

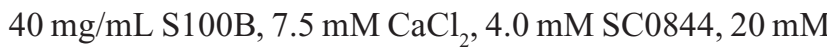
Tris buffer, at $\mathrm{pH} 7.2$, reservoir solutions, ie, SC0332$\mathrm{Ca}^{2+}-\mathrm{S} 100 \mathrm{~B}, 50 \mathrm{mM} \mathrm{MgCl}, 0.1 \mathrm{M}$ HEPES buffer at $\mathrm{pH}$ 7.4, and 34\% PEGMME550; SC0844-Ca ${ }^{2+}-\mathrm{S} 100 \mathrm{~B}, 7.5 \mathrm{mM}$ $\mathrm{CaCl}_{2}, 0.2 \mathrm{M} \mathrm{Li}_{2} \mathrm{SO}_{4}, 62.5 \mathrm{mM}$ cacodylate buffer at $\mathrm{pH} 8.5$, and $38 \%$ PEG3350) and harvest solutions ( $\mathrm{SC} 0332-\mathrm{Ca}^{2+}$ $\mathrm{S} 100 \mathrm{~B}, 7.5 \mathrm{mM} \mathrm{CaCl}_{2}, 50 \mathrm{mM} \mathrm{MgCl}, 4.0 \mathrm{mM} \mathrm{SC} 0332$, 0.1 M HEPES buffer at pH 7.4, 34\% PEGMME550, and
5\% glycerol; SC0844-Ca ${ }^{2+}-\mathrm{S} 100 \mathrm{~B}, 7.5 \mathrm{mM} \mathrm{CaCl}_{2}, 0.1 \mathrm{M}$ $\mathrm{Li}_{2} \mathrm{SO}_{4}, 0.5 \mathrm{mM} \mathrm{SC0844,27.5} \mathrm{mM}$ Tris buffer at $\mathrm{pH} 8.5$, $39 \%$ PEG3350, and 5\% glycerol). Space groups and unit cell parameters are given in Table 1. SC0067-Ca ${ }^{2+}-\mathrm{S} 100 \mathrm{~B}$, SC0332-Ca ${ }^{2+}-\mathrm{S} 100 \mathrm{~B}$, and SC0844-Ca ${ }^{2+}-\mathrm{S} 100 \mathrm{~B}$ had four, one, and two S100B subunits in the asymmetric unit, respectively.

\section{X-ray data collection, model building, and refinement}

$\mathrm{X}$-ray data for SC0067-Ca ${ }^{2+}-\mathrm{S} 100 \mathrm{~B}$ were collected at $100 \mathrm{~K}$ using an in-house X-ray generator (MSC Micro$\max 7$, Rigaku, TX) and a Raxis-4++ image plate detector (Rigaku, TX). X-ray data for crystals SC0332-Ca ${ }^{2+}-\mathrm{S} 100 \mathrm{~B}$ and SC0844-Ca ${ }^{2+}-\mathrm{S} 100 \mathrm{~B}$ were collected remotely at Stanford Synchrotron Radiation Laboratory (beamlines 9-1 and 12-2, respectively, Menlo Park, CA) using an ADSC Quantum-315 CCD detector (Area Detector Systems Corp., Poway, CA) and a MAR325 CCD detector (Marresearch, Germany), respectively. The reflection intensities were integrated and scaled with the HKL2000 suite of computer programs. ${ }^{41}$ The crystals of SC0067-Ca ${ }^{2+}-\mathrm{S} 100 \mathrm{~B}, \mathrm{SC} 0332-\mathrm{Ca}^{2+}-\mathrm{S} 100 \mathrm{~B}$, and SC0844-Ca ${ }^{2+}-\mathrm{S} 100 \mathrm{~B}$ diffracted to $2.04 \AA, 1.79 \AA$, and $1.85 \AA$ resolution, respectively. Preliminary phases were obtained via molecular replacement techniques using the structure of $\mathrm{Ca}^{2+}$-bound S100B (PDB file: $1 \mathrm{MHO}$ ) as a search model and the computer program phaser from the $\mathrm{CCP} 4$ program suite. ${ }^{42,43}$ Refinement and model building was completed using REFMAC5 and COOT. ${ }^{44,45}$ The locations of the SC inhibitors and several water molecules were determined by visual inspection of electron density maps calculated with $2 \mathrm{mF}_{\mathrm{o}}-\mathrm{DF}_{\mathrm{c}}$ and $\mathrm{mF}_{\mathrm{o}}-\mathrm{DF}_{\mathrm{c}}$ coefficients using COOT. ${ }^{45}$ It was evident from visual inspection of the $2 \mathrm{mF}_{\mathrm{o}}-\mathrm{DF}_{\mathrm{c}}$ and $\mathrm{mF}_{\mathrm{o}}-\mathrm{DF}_{\mathrm{c}}$ electron density maps that $\mathrm{SC} 0067$ was bound to only two monomers of the four in the asymmetric unit and the occupancy of both chlorpromazine molecules was 1.0. The mercury for the SC0332 molecule was covalently linked to the Cys 84 with the mercury at an occupancy of 0.25 . The other half of SC0332 found in the hydrophobic pocket was set to an occupancy of 1, except for the sulfur which was set to an occupancy of 0.25 . SC0844 occupancy was set to 1.0 and was covalently attached to the Cys 84 sulfur similar to the mercury of SC0332 (see Table 1). The stereochemistry was checked with the programs WHATCHECK and PROCHEK. ${ }^{46,47}$ The quaternary structure and accessible surface areas were analyzed using the PISA server (http://www.ebi.ac.uk/msd-srv/ prot_int/cgi-bin/piserver). The coordinates for SC0067$\mathrm{Ca}^{2+}-\mathrm{S} 100 \mathrm{~B}, \mathrm{SC} 0332-\mathrm{Ca}^{2+}-\mathrm{S} 100 \mathrm{~B}$, and SC0844-Ca ${ }^{2+}-\mathrm{S} 100 \mathrm{~B}$ 
Table I Diffraction and refinement statistics

\begin{tabular}{|c|c|c|c|}
\hline & $\begin{array}{l}\mathrm{SC} 0067 \\
\mathrm{Ca}^{2+}-\mathrm{SIOOB}\end{array}$ & $\begin{array}{l}\mathrm{SC} 0322 \\
\mathrm{Ca}^{2+}-\mathrm{S} 100 \mathrm{~B}\end{array}$ & $\begin{array}{l}\mathrm{SC} 0844 \\
\mathrm{Ca}^{2+}-\mathrm{S} 100 \mathrm{~B}\end{array}$ \\
\hline \multicolumn{4}{|l|}{ Diffraction statistics } \\
\hline Space group & $\mathrm{P} 2_{1}$ & C222, & $\mathrm{P}_{2} 2 \mathrm{I}$ \\
\hline Cell dimensions a,b,c $(\AA)$ & $28.6,59.1,104.0$ & $35.2,88.8,59.0$ & $46.3,46.3,172.4$ \\
\hline Cell angles $\alpha, \beta, \gamma(\mathrm{deg})$ & $90,92.5,90$ & $90,90,90$ & $90,90,120$ \\
\hline \multirow[t]{2}{*}{ Resolution $(\AA)$} & $103.7-2.04$ & $44.4 I-1.79$ & $57.45-1.85$ \\
\hline & $(2.09-2.04)$ & $(1.84-1.79)$ & $(1.89-1.85)$ \\
\hline Unique reflections (n) & $20393(1190)$ & $7229(188)$ & $18153(1202)$ \\
\hline Completeness (\%) & $96.86(79.95)$ & $84.36(30.40)$ & 99.27 (93.01) \\
\hline $\mathrm{R}_{\text {sym }}{ }^{\mathrm{a}}$ & $0.075(0.428)$ & $0.057(0.308)$ & $0.055(0.519)$ \\
\hline Average $I / \sigma$ & $14.14(2.94)$ & $29.09(2.31)$ & $37.48(2.80)$ \\
\hline Multiplicity & $4.0(4.0)$ & $5.9(3.4)$ & $9.6(6.4)$ \\
\hline \multicolumn{4}{|l|}{ Refinement statistics } \\
\hline $\mathrm{R}_{\text {crys }}^{\mathrm{b}}(\%)$ & 23.7 (19.7) & $19.8(23.6)$ & $19.5(24.1)$ \\
\hline $\mathrm{R}_{\text {free }}^{\mathrm{b}}(\%)$ & $29.1(29.3)$ & $24.2(28.8)$ & $21.8(24.1)$ \\
\hline Protein atoms & 2887 & 704 & |48| \\
\hline Water molecules & 82 & 47 & 127 \\
\hline Nonhydrogen atoms & 3014 & 779 & 1658 \\
\hline \multicolumn{4}{|l|}{ Mean B-values $\left(\AA^{2}\right)$} \\
\hline Overall & 44.54 & 48.52 & 33.90 \\
\hline Protein atoms & 43.48 & 48.48 & 33.61 \\
\hline Water molecules & 47.03 & 63.46 & 37.48 \\
\hline $\mathrm{Ca}^{2+}$ ions & 39.69 & 43.58 & 31.29 \\
\hline small molecules & 113.50 & $56.37,91.30$ & 33.62 \\
\hline \multicolumn{4}{|c|}{ Root-mean-squared difference } \\
\hline Bond length $(\AA)$ & 0.017 & 0.012 & 0.012 \\
\hline Bond angles $(\AA)$ & $\mathrm{I} .557$ & 1.427 & 2.166 \\
\hline \multicolumn{4}{|l|}{ Ramachandran plot (\%)c } \\
\hline Most favored & 94.9 & 91.5 & 95.2 \\
\hline Additionally allowed & 5.1 & 6.1 & 4.8 \\
\hline Generously allowed & 0.0 & 2.4 & 0.0 \\
\hline PDB identification & 3LKO & $3 \mathrm{LKI}$ & 3 LLE \\
\hline
\end{tabular}

Notes: Numbers in parentheses represent the last outer shell. ${ }^{\mathrm{a} R s y m}=\Sigma \mathrm{h} \Sigma \mathrm{i}(\| \mathrm{li}(\mathrm{h})|-|\{\mid(\mathrm{h})\} \mid) / \Sigma \mathrm{h} \Sigma \mathrm{ilj}(\mathrm{h})$, where li(h)= observed intensity, and $\{l(\mathrm{~h})\}=$ mean intensity obtained from multiple measurements. ${ }^{b}$ Rcrys and Rfree $=\Sigma|| \mathrm{Fo}|-| \mathrm{Fc}|| \Sigma|| \mathrm{Fo} \mid$, where $|\mathrm{Fo}|=$ observed structure factor amplitude and $|\mathrm{Fc}|=$ calculated structure factor amplitude for the working and test sets, respectively. ${ }^{\mathrm{C}}$ For SC0833- $\mathrm{Ca}^{2+}-\mathrm{SIOOB}$ the calculations had 160 residues in the most favored region and eight residues in additionally allowed regions.

X-ray structure were deposited in the Protein Databank and assigned the following accession numbers: $3 \mathrm{LK} 0$ for SC0067-Ca ${ }^{2+}-\mathrm{S} 100 \mathrm{~B}, 3 \mathrm{LK} 1$ for SC0332- $\mathrm{Ca}^{2+}-\mathrm{S} 100 \mathrm{~B}$, and 3LLE for SC0844-Ca ${ }^{2+}-\mathrm{S} 100 \mathrm{~B} .{ }^{48,49}$ Figures were generated with the program PyMol (http://www.pymol.org).

\section{Results and discussion Fluorescence polarization competition assay development}

Fluorescence polarization assays have been used for HTS applications due to their high sensitivity, rapid readout, homogenous format, and relatively simple instrumentation. However, such assays require optimization to develop a rapid and sensitive method for efficient and reliable screening of large compound libraries. Some of these issues are not necessarily exclusive to polarization assays, or even fluorescent-based assays, but had to be addressed when developing the assay for discovering S100B inhibitors.

\section{Fluorescence polarization competition assay buffer}

The buffer originally used was based on the conditions used for the NMR structure determination of peptide-bound S100B (10 mM Tris, pH 6.5, $15 \mathrm{mM} \mathrm{NaCl}, 10 \mathrm{mM} \mathrm{CaCl}_{2}$ ) but was modified to represent intracellular conditions better with the addition of $100 \mathrm{mM} \mathrm{KCl} .^{22,24} \mathrm{The} \mathrm{pH}$ and buffer was switched to $50 \mathrm{mM}$ HEPES, $\mathrm{pH}$ 7.2, in place of Tris, $\mathrm{pH}$ 6.5, again to mimic better intracellular $\mathrm{pH}$ and to provide a higher buffering capacity as necessary to prevent compounds from changing $\mathrm{pH}$. This is important during an HTS scenario in 
which the $\mathrm{pH}$ is not trivial to adjust after the addition of each compound. It was also necessary to add 5\% DMSO and $0.1 \%$ Triton $\mathrm{X}-100$ to provide the optimal conditions for compound solubility.

Typically, compound libraries used for HTS screens are prepared in $100 \%$ DMSO due to its ability to dissolve a wide range of compounds. The FPCA assay will be used to screen relatively high concentrations of compound, so even weakly binding compounds including those that bind with low micromolar affinities could be identified; under such conditions, the final concentration of DMSO would also increase. Therefore, it was necessary to determine a concentration of DMSO that appreciably solubilized the compounds in aqueous solutions, but had a minimal affect on peptide binding. ${ }^{50}$ With this in mind, the affinity of S100B for target peptide was tested under varying concentrations of DMSO. In the final FPCA, 5\% DMSO was used because it only decreased the affinity for the peptide minimally ( $<2.0$-fold) and allowed a high enough concentration of compound to be screened, consistent with previous studies showing that the use of 5\% DMSO or greater increases the solubility of some of the compounds in aqueous solutions. ${ }^{50}$

The inclusion of Triton X-100 in the FPC assay was done to reduce false positives caused by compounds that themselves form aggregates and, in turn, sequester proteins nonspecifically. Compounds such as these, termed "promiscuous binders", need to be minimized, as previously described. ${ }^{51,52}$ The FPCA was tested on the same library of compounds in the absence and presence of either $0.05 \%$ or $0.10 \%$ Triton X-100 in order to identify "promiscuous binders". While both $0.10 \%$ and $0.05 \%$ Triton X-100 effectively reduced such false positives in the FPCA, it was decided that $0.10 \%$ Triton X-100 would be used in the final assay as a cautious measure. As an additional benefit, the addition of Triton X-100, like the small amount of DMSO, also increased the solubility of many of the compounds.

\section{Selection of fluorescently-labeled peptide probes}

Several peptides have been found to bind S100B with different affinities, including one derived from p53, CapZ (TRTK-12), Hdm2, and Hdm4. ${ }^{18}$ These peptides were also synthesized with a specific N-terminal FITC or TAMRA label. To screen for inhibitors of the S100B-p53 interaction, it seemed logical to use a peptide based on the well-characterized C-terminal peptide of $\mathrm{p} 53$, and initially the FPCA was performed with a peptide comprising residues 367-393 of human p53 with a single FITC conjugated to its amino-terminus (FITC-p53 ${ }^{367-393}$ ). This peptide was shown to bind to $\mathrm{Ca}^{2+}-\mathrm{S} 100 \mathrm{~B}$ by fluorescence polarization, and could be competed off with the unlabeled p53, TRTK-12, and Hdm4 peptides, showing that the four peptides bind in the same location on S100B. However, the $\mathrm{K}_{\mathrm{D}}$ of FITC-p $53^{367-393}$ was found to have a significantly higher affinity than the unlabeled version, indicative of the FITC moiety contributing to the binding interaction. In addition, the fluorescence lifetime of the FITC varies with $\mathrm{pH}$, so any slight change in $\mathrm{pH}$ could result in a false-positive reading. Lastly, it is also documented that FITC is sensitive to the solutions redox state, which is another source of false-positive readings, particularly with numerous compounds in the Spectrum Collection library. ${ }^{53}$ Thus, for compounds such as these, a time-dependence and sensitivity to reducing agents was noted, again due to the physical characteristics of FITC responding to the solutions redox state and not as the result of binding to S100B. To avoid these problems with the use of FITC, the N-terminal TAMRA-labeled peptides were used here.

A TAMRA-labeled version of the $\mathrm{p} 53$ peptide (TAMRAp53 $3^{367-393}$ ), TRTK-12 (TAMRA-TRTK), and Hdm4 (TAMRA$\mathrm{Hdm} 4$ ) were synthesized, and their affinities for S100B determined under assay conditions. The TAMRA- $553^{367-393}$, TAMRA-TRTK, and TAMRA-Hdm4 were found to have $\mathrm{K}_{\mathrm{D}}$ values of $25.39 \pm 2.97 \mu \mathrm{M}, 1.19 \pm 0.65 \mu \mathrm{M}$ (see Figure 3A), and $3.08 \pm 0.39 \mathrm{nM}$, respectively. The particularly high affinity of the Hdm4 peptide was surprising, and the peptide can be used in secondary screens for the highest binding inhibitors discovered. However, this peptide would not be useful for screening large libraries because the probe concentration would have to be $<1 \mathrm{nM}$, which is too low to make accurate polarization readings for many commercially available plate readers. On the other hand, the relatively low affinity binding of the TAMRA-p $53^{367-393}$ peptide would require high concentrations of S100B that would be prohibitive to complete a screen of a large compound library. However, the affinity of the TAMRA-TRTK peptide for S100B was ideally suited to accommodate sufficient screening ability without the need for extremely large quantities of protein. For these reasons, it was chosen for use in the FPCA assay. The dynamic range for measuring polarization for this peptide in the free and bound state was also favorable, with the free TAMRA-TRTK peptide giving a polarization value of $134.2 \pm 5.1 \mathrm{mP}$ that increased to $308.2 \pm 7.4 \mathrm{mP}$ with saturating $\mathrm{S} 100 \mathrm{~B}(>99.5 \%$ occupancy). For the most sensitive polarization competition assay, the fraction of [ligand bound]/[total ligand] should be between 0.5 and 0.8 , with the total ligand (TAMRA-TRTK) being $2 \times \mathrm{K}_{\mathrm{D} ;}^{54}$ therefore, $2.5 \mu \mathrm{M} \mathrm{S100B}$ was used with 
$50 \mathrm{nM}$ TAMRA-TRTK for a fractional occupancy of 0.67 , within the range. When the FPCA assay was run under these conditions, a $\mathrm{Z}$ factor of 0.71 is obtained, which is within the acceptable range of 0.5-1.0 (see Material and Methods section for calculation). ${ }^{30}$

\section{High-throughput screen using FPCA}

As illustrated (see Figure 2), the TAMRA-TRTK FPCA was used to screen the 2000-compound Spectrum Collection library, and 26 compounds were identified as possible S100B inhibitors. The assay was done in a high-throughput mode using four different concentrations of compound, ie, $62.5,31.3,15.6$, and $7.8 \mu \mathrm{M}$. Under these conditions, compounds that inhibited the binding by at least twice the standard deviation from the mean values of all the tested compounds were considered to be top candidate inhibitors (see Figure 3C). Using these selection criteria, there were $39(2.0 \%), 39(2.0 \%), 37(1.9 \%)$, and 32 (1.6\%) compounds from the 2000 total that were selected for secondary screens for the $62.5,31.3,15.6$, and $7.8 \mu \mathrm{M}$ concentrations, respectively. Several other compounds were initially identified because they appeared to increase the binding to the peptide. However, upon closer inspection, these compounds were causing fluorescence interference (FI) with the assay. The FI could be due to the compound having overlapping fluorescence, quenching the fluorophore, and/or changing the fluorescence lifetime of the probe. Once these compounds were eliminated from further consideration, a total of 49 compounds were selected for secondary screening using NMR, with 26 compounds meeting the selection criteria (Figure 4). In the end, it was determined that all 26 compounds shown to bind S100B using the NMR secondary screening method would have been selected using either the 31.3 or $62.5 \mu \mathrm{M}$ concentrations alone. Nonetheless, the use of four concentrations is still in use because it also allows for an estimation of the $\mathrm{IC}_{50}$, and also allows for easy identification of FI in the FPCA that might not be seen using a single concentration. However, for very large screens, to save material, the assay can be reliably completed using only 31.3 or $62.5 \mu \mathrm{M}$.

\section{Secondary screening of compounds by NMR}

The monitoring of NMR chemical shift perturbations for ${ }^{1} \mathrm{H}$ and ${ }^{15} \mathrm{~N}$ resonances in $\mathrm{S} 100 \mathrm{~B}$ upon the addition of compound was used as a secondary screen of the top 49 compounds identified from the FPCA. These NMR data were important to eliminate false positives as well as to provide residuespecific information for mapping the compound binding site on $\mathrm{Ca}^{2}$-bound $\mathrm{S} 100 \mathrm{~B}$. For such measurements, recombinant S100B protein was produced with ${ }^{15} \mathrm{~N}$ ammonium chloride as its only nitrogen source, so backbone ${ }^{15} \mathrm{~N}$ amide and ${ }^{1} \mathrm{H}_{\mathrm{N}}$ protons could be readily detected in the presence and absence of the small molecule inhibitor using the ${ }^{1} \mathrm{H}-{ }^{15} \mathrm{~N}$ edited HSQC experiment. However, collecting HSQC data such as these is not as rapid as with the FPCA, such that it is most useful as a secondary screen when only a limited number of samples need to be examined. For example, the automatic sample changers commercially available for NMR spectrometers typically hold 60 to 250 samples, with each sample requiring two 10-minute periods of data collection. Here, the samples were all prepared using 10-fold excess compound versus S100B (100 $\left.\mu \mathrm{M} ; 10 \mathrm{mM} \mathrm{Ca}^{2+}\right)$. These data were compared with a $\mathrm{S} 100 \mathrm{~B}$ spectrum in the absence of compound, and only compounds that caused changes in

A
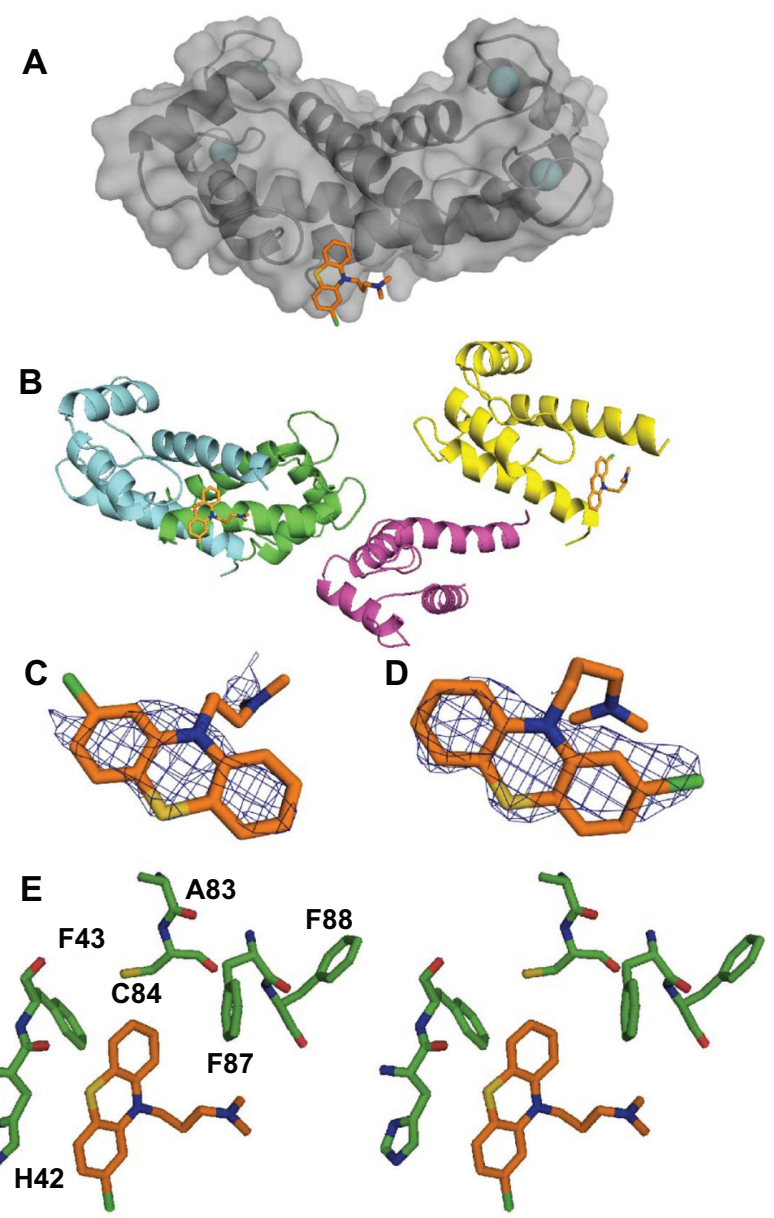

Figure 5 X-ray structure of the chlorpromazine (SC0067)-Ca ${ }^{2+}-\mathrm{SI} 00 \mathrm{~B}$ complex. A) Surface diagram illustrating the location of the chlorpromazine molecule. B) Ribbon diagram illustrating the asymmetric unit of SC0067-Ca ${ }^{2+}-\mathrm{SIOOB}$ having only two SIOOB monomers occupied with chlorpromazine. C and D) Electron density maps calculated with the $2 \mathrm{mF}_{\mathrm{o}}-\mathrm{DF}_{\mathrm{c}}$ coefficients $(I .0 \sigma)$ for each of the chlorpromazine molecules modeled. E) Residues of SI00B with $5 \AA$ of chlorpromazine are illustrated. (Protein Databank accession number: 3LK0). 
the chemical shift values and/or caused loss of peaks due to chemical exchange broadening were considered to be $\mathrm{S} 100 \mathrm{~B}$ inhibitors. In addition to these data providing confirmation compound binding, the NMR chemical shift perturbations also provide residue-specific data that are useful for defining the compound binding site on the protein in solution, particularly given that the high resolution structure of $\mathrm{Ca}^{2+}-\mathrm{S} 100 \mathrm{~B}$ is known (see Figure 6A).

The NMR screening confirmed that 26 of the 49 compounds identified in the FPCA assay were indeed binding $\mathrm{Ca}^{2+}$-bound S100B. Many of the "false-positive" hits originally identified in the FPCA were subsequently found to possess intrinsic fluorescence that directly interfered with fluorescence polarization (ie, FI). However, nine compounds initially selected in the FPCA, but later shown to have FI in the FPCA, did in fact still bind S100B as determined by NMR. Therefore, it is not recommended to have a prescreen to eliminate compounds that potentially have FI in the FPCA.
For example, two compounds, SC0931 and SC1036, are structurally very similar. In a quantitative titration using the FPCA, SC0931 was found to bind to $\mathrm{Ca}^{2+}$-S100B with the highest affinity $\left(\mathrm{K}_{\mathrm{D}}=0.04 \pm 0.01 \mu \mathrm{M}\right)$ of all the compounds that were discovered here $\left(0.04 \mu \mathrm{M}<\mathrm{K}_{\mathrm{D}}<1500 \mu \mathrm{M}\right)$; whereas the affinity of SC1036 could not be determined quantitatively in the FPCA due to FI. Thus, this compound showed some binding in the initial screen and was found to bind S100B by NMR. If a prescreen that eliminated the testing of compounds with FI, then SC1036 would not have been included in the NMR screen and hence not discovered as a potential lead. In addition, it should also be noted that the intrinsic fluorescence of a compound, while interfering with quantitative interpretation of the FPCA screen, is useful for monitoring binding via direct fluorescence changes (ie, as was the case with SC0844, see Table 2 and Figure 10). For the other nine compounds that had FI but were determined to bind S100B via NMR, only very rough estimates of their binding affinities

Table 2 Summary of the 26 compounds confirmed to bind SI00B by NMR

\begin{tabular}{|c|c|c|c|c|}
\hline Compound & NMR $^{a}$ & $I C_{50}(\mu M)^{b}$ & $K_{D}(\mu M)^{c}$ & Cys dependent \\
\hline SC0025 & Yes & $\mathrm{FI}$ & $\mathrm{FI}$ & No \\
\hline SC0067 & Yes & $2222.0 \pm 1364.3$ & $696.9 \pm 427.9$ & No \\
\hline SC0332 & Yes & $177.7 \pm 16.5$ & $55.2 \pm 5.1$ & Yes \\
\hline SC0345 & Yes & $1576.7 \pm 274.3$ & $494.3 \pm 86.0$ & No \\
\hline SC0377 & Yes & $4.4 \pm 2.2$ & $0.78 \pm 0.39$ & Yes \\
\hline SC0676 & Yes & $606.6 \pm 370.7$ & $189.8 \pm 116.0$ & Yes \\
\hline SC0844 & Yes & $35.9 \pm 16.4$ & $\begin{array}{l}10.7 \pm 4.9 \\
\left(5.8 \pm 0.2^{\mathrm{d}}\right)\end{array}$ & Yes \\
\hline SC093I & Yes & $2.0 \pm 0.6$ & $0.04 \pm 0.01$ & No \\
\hline SCI036 & Yes & $\mathrm{FI}$ & $\mathrm{FI}$ & No \\
\hline SCI 050 & Yes & $7.6 \pm 2.1$ & $1.79 \pm 0.50$ & Yes \\
\hline SCII9I & Yes & $\mathrm{FI}$ & $\mathrm{FI}$ & Yes \\
\hline SCII93 & Yes & $\mathrm{FI}$ & $\mathrm{FI}$ & Yes \\
\hline SCI 222 & Yes & $1926.1 \pm 1050.6$ & $604.0 \pm 329.5$ & Yes \\
\hline SCI 228 & Yes & $832.0 \pm 381.3$ & $260.6 \pm 119.4$ & Yes \\
\hline SCI23I & Yes & $\mathrm{FI}$ & $\mathrm{FI}$ & Yes \\
\hline SCI 233 & Yes & $4689.2 \pm 4521.2$ & $|47| .4 \pm|4| 8.7$ & Yes \\
\hline SCI 403 & Yes & $1615.1 \pm 906.0$ & $506.4 \pm 284.1$ & Yes \\
\hline SCI462 & Yes & $420.1 \pm 66.8$ & $131.3 \pm 20.9$ & Yes \\
\hline SCI475 & Yes & $133.1 \pm 65.0$ & $41.2 \pm 20.1$ & Yes \\
\hline SCI 649 & Yes & $\mathrm{FI}$ & $\mathrm{FI}$ & Yes \\
\hline SCI 707 & Yes & $\mathrm{FI}$ & $\mathrm{FI}$ & Yes \\
\hline SCI 778 & Yes & $\mathrm{FI}$ & $\mathrm{FI}$ & Yes \\
\hline SCI92I & Yes & $13.0 \pm 3.5$ & $3.5 \pm 0.9$ & No \\
\hline SCI 928 & Yes & $728.4 \pm 698.7$ & $228.1 \pm 218.8$ & Yes \\
\hline SCI982 & Yes & $\mathrm{FI}$ & $\mathrm{FI}$ & Yes \\
\hline SCI990 & Yes & $1349.2 \pm 698.7$ & $422.9 \pm 219.0$ & No \\
\hline
\end{tabular}

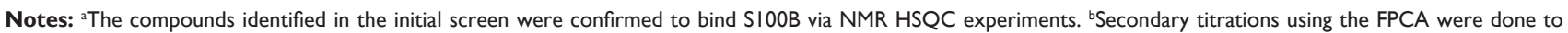
determine $I C_{50}$ of the compounds, however, fluorescence interference (FI), from overlapping fluorescence, quenching, etc..., prevented an exact IC $\mathrm{C}_{50}$ from being determined for certain compounds. 'When available, the $\mathrm{IC}_{50}$ from the FPCA was used to calculate the $\mathrm{K}_{\mathrm{D}}$ using the equation as described by Nikolovska-Coleska et a ${ }^{3 !}$. ${ }^{\mathrm{d}} \mathrm{Change}$ in the compounds intrinsic fluorescence was used to determine the $K_{D}$.

Abbreviations: NMR, nuclear magnetic resonance; cmpd, compound; cys, cysteine; FI, fluorescence interference; HSQC, heteronuclear single quantum coherence; FPCA, fluorescence polarization competition assay. 


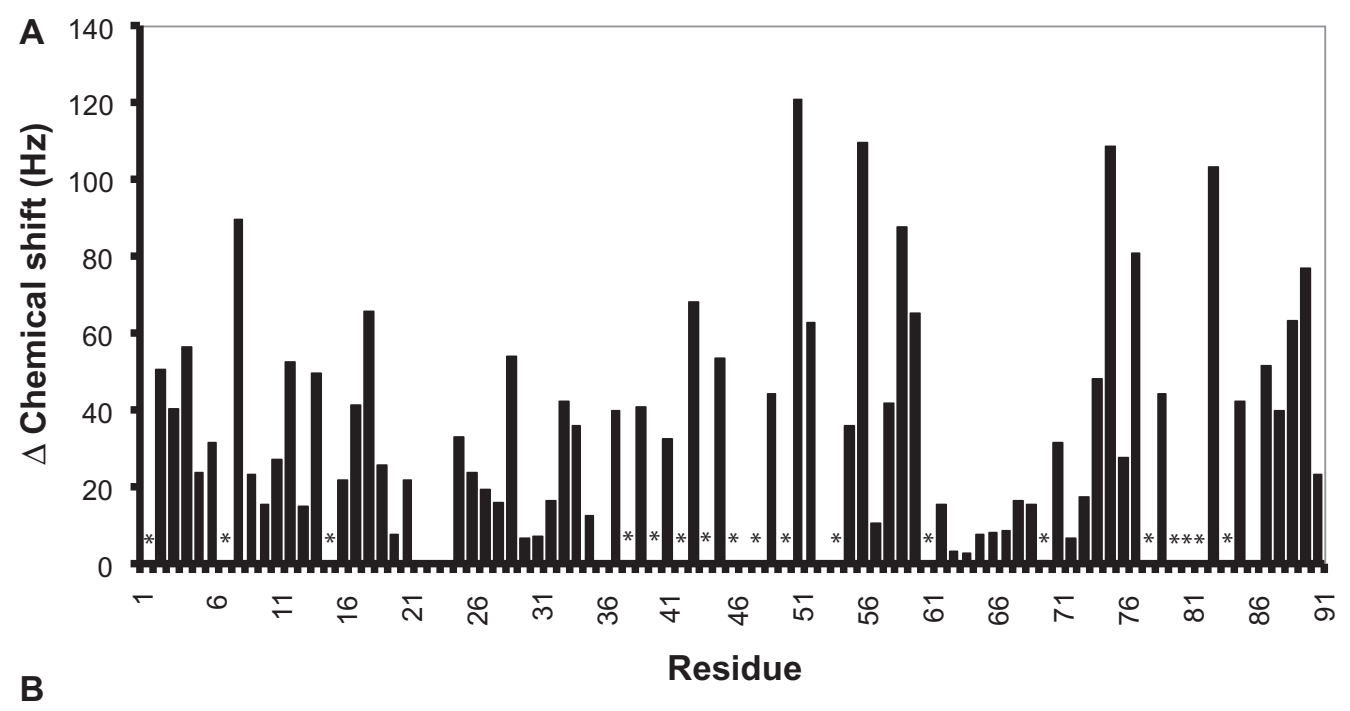<smiles>CN(C)CCCN1c2ccccc2Sc2ccc(Cl)cc21</smiles>

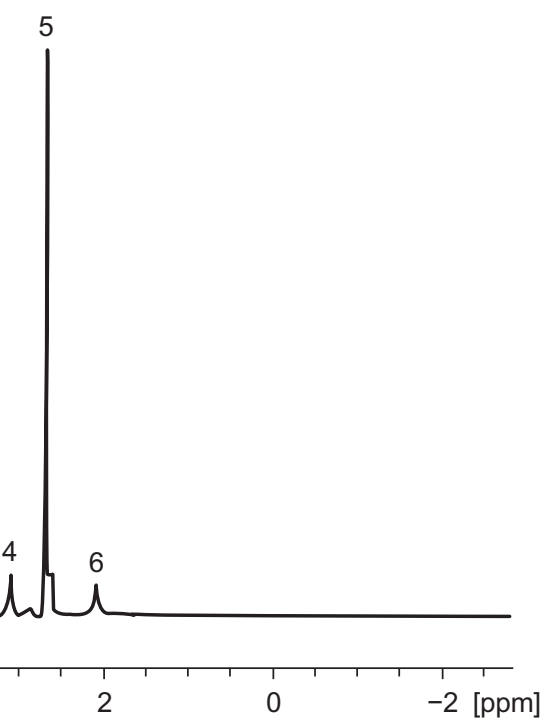

Figure 6 NMR data for the SC0067-SI00B complex. A) The binding of chlorpromazine (SC0067) to Ca ${ }^{2+}-$ SI00B was monitored by HSQC NMR titrations and the combined perturbation in the chemical shifts of the backbone amide and proton were graphed. The asterisk indicates the peak was lost due to chemical exchange broadening. B) The binding of chlorpromazine (SC0067) to $\mathrm{Ca}^{2+}-\mathrm{SIOOB}$, as monitored by saturation transfer difference, NMR spectroscopy showing the strongest peaks for the atoms closest to SIO0B.

Abbreviations: HSQC, heteronuclear single quantum coherence; NMR, nuclear magnetic resonance.

could be obtained at this time, and they remain compounds of interest for further investigation. In order to provide further structural details of how the compounds identified interact with S100B, several of the compound-S100B complexes were crystallized and their structures determined at atomic resolution.

\section{Structural studies of the chlorpromazine- $\mathrm{Ca}^{2+}-\mathrm{SI}$ 00B complex}

The X-ray structure of chlorpromazine bound to $\mathrm{Ca}^{2+}-\mathrm{S} 100 \mathrm{~B}$ was solved at $2.04 \AA$ resolution (see Figure 5 and Table 1). In the chlorpromazine- $\mathrm{Ca}^{2+}-\mathrm{S} 100 \mathrm{~B}$ structure, the asymmetric unit included four subunits of S100B monomers designated
A-D; models A and B of the monomers formed the biologically active dimeric form of S100B. Each monomer in the $\mathrm{Ca}^{2+}-\mathrm{S} 100 \mathrm{~B}$ structure contained Met- 0 to Glu-89, eight calcium ions, and two chlorpromazine molecules. Models A and $\mathrm{D}$, each a monomer representing half of the biological dimer, had a bound chlorpromazine molecule. In the final refined models, residues of S100B in the chlorpromazine$\mathrm{Ca}^{2+}-\mathrm{S} 100 \mathrm{~B}$ complex were nearly all in the most favorable region of their respective Ramachandran plots (95\%) with the remaining residues falling into the allowed region $(5 \%$, see Table 1).

As expected, the two EF-hand calcium binding domains in each subunit were found to coordinate two 
$\mathrm{Ca}^{2+}$ ions, as found previously with the typical EF-hand of $\mathrm{S} 100 \mathrm{~B}$ in the $\mathrm{Ca}^{2+}$-bound "open" conformation and the dimer interface aligned as a symmetric X-type four helix bundle comprising helices 1,1 ' and 4, 4', respectively (see Figure 1). ${ }^{27,55-58}$ The global fold for S100B in all four monomers in the chlorpromazine- $\mathrm{Ca}^{2+}-\mathrm{S} 100 \mathrm{~B}$ complex was similar to that reported for $\mathrm{Ca}^{2+}$-bound $\mathrm{S} 100 \mathrm{~B}, \mathrm{Zn}^{2+}, \mathrm{Ca}^{2+}-\mathrm{S} 100 \mathrm{~B}$, and several other $\mathrm{Ca}^{2+}$-loaded S100 proteins. ${ }^{59-62}$ The binding of chlorpromazine compound caused only minor structural perturbations, as evidenced by low root-mean-square distance (RMSD) values between the chlorpromazine-bound monomers in the asymmetric unit compared with unbound structures in the asymmetric unit (mainchain $\mathrm{RMSD} \approx 0.27 \AA$ ). ${ }^{42,58}$ Specifically, each subunit of S100B in the chlorpromazine- $\mathrm{Ca}^{2+}-\mathrm{S} 100 \mathrm{~B}$ complexes contained four helices (helix 1, E2-G19; helix 2, K28-L40; helix 3, E49-D61; helix 4, D69-F88) and one small antiparallel $\beta$-sheet (strand 1, K26-K28; strand 2, D69-E67).

It was necessary to model the chlorpromazine molecule into sparse electron density in only two of the asymmetric units of S100B, with each molecule having an occupancy of 1 . Modeling chlorpromazine into the electron density maps calculated with $2 \mathrm{mF}_{\mathrm{o}}-\mathrm{DF}_{\mathrm{c}}$ and $\mathrm{mF}_{\mathrm{o}}-\mathrm{DF}_{\mathrm{c}}$ coefficients showed that the chlorpromazine molecule was oriented in the hydrophobic pocket of $\mathrm{Ca}^{2+}-\mathrm{S} 100 \mathrm{~B}$ with the tricyclic

moiety nearby several hydrophobic residues on the hinge (H42 and F43) and helix 4 (A83, C84, F87, and F88). The dimethylamine moiety of chlorpromazine was found to be extending toward the C-terminal end of S100B (F87 and F88). Overall, the S100B-chlorpromazine interaction was stabilized via hydrophobic interactions, with residues in loop 2 (H42, F43) and in helix 4 (A83, C84, F87, F88) contributing most to binding (see Figure 5). The X-ray structure of the chlorpromazine-Ca $\mathrm{Ca}^{2+}-\mathrm{S} 100 \mathrm{~B}$ complex is fully consistent with chemical shift perturbation and saturation transfer difference data collected in solution by NMR (see Figure 6). The binding of chlorpromazine to $\mathrm{Ca}^{2+}-\mathrm{S} 100 \mathrm{~B}$ was measured by monitoring perturbations of backbone ${ }^{1} \mathrm{H}-{ }^{15} \mathrm{~N}$ correlations in two-dimensional ${ }^{1} \mathrm{H}-{ }^{15} \mathrm{~N}$ NMR experiments (see Figure 6A). In HSQC titrations with chlorpromazine the ${ }^{1} \mathrm{H}-{ }^{15} \mathrm{~N}$ HSQC correlations of $\mathrm{Ca}^{2+}{ }_{-} \mathrm{S} 100 \mathrm{~B}$ shifted for several residues in helix 1 (E2, E4, V8, D12, F14, S18), loop 1 (K29), loop 2 (F43, E45, E49, and E51), helix 3 (V52, V56, T59, and L60) and helix 4 (M74, A75, V77, M79, A83, F87, E89, and H90). The strength of the STD-NMR signals for the methyl group protons from the rings of the molecule, and the methyl protons on the tertiary nitrogen interact closely with S100B (see Figure 6B). In addition, the location of the chlorpromazine overlaps the binding site found for other S100B inhibitors (see Figure 7)..$^{19,60}$


Figure 7 Comparison of X-ray structures of small molecules bound to SI00B. Surface diagrams of chlorpromazine (SC0067)-Ca ${ }^{2+}-\mathrm{SI00B}$-ray structure is shown overlaid with other small molecules previously crystallized with Ca ${ }^{2+}-\mathrm{SIO0B}$ : (A) SBil 32, (B) SBi279, (C) SBi523, and (D) pentamidine. ${ }^{19,60}$ 

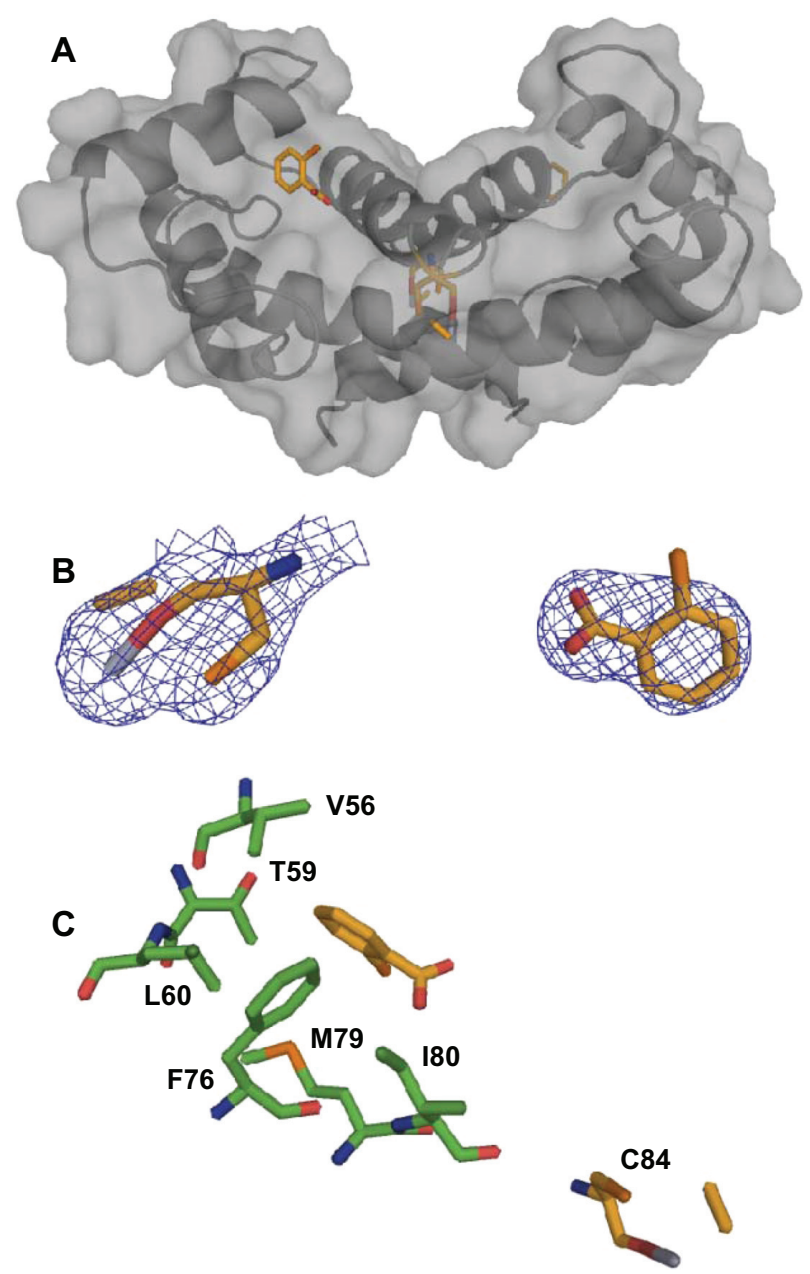

Figure 8 The X-ray structure of thimerosal SC0332-Ca ${ }^{2+}-\mathrm{SIO0B}$. A) Ribbon and surface diagram of SC0332- $\mathrm{Ca}^{2+}-\mathrm{SI}$ 00B illustrating the location of SC0322 (SC0322, orange; nitrogen, blue; oxygen, red; sulfur, orange) with one mercury moiety covalently bound to Cys84 and the benzene in the hydrophobic pocket. B) The electron density maps calculated with the $2 \mathrm{mF}$-DF coefficients (I.0 $\sigma)$ for $\mathrm{SC} 0322$ in each site. C) Residues of SIOOB within $4 \AA$ of SC0322 bound to benzene site and depicting the distance from Cys84 that is modified by the mercury. (Protein Databank accession number: 3LKI).

\section{Structural studies of thimerosal- $\mathrm{Ca}^{2+}-\mathrm{SIOOB}$}

The X-ray structure of $\mathrm{SC} 0332$ bound to $\mathrm{Ca}^{2+}-\mathrm{S} 100 \mathrm{~B}$ was solved in the $\mathrm{C} 222$ space group at $1.79 \AA$ resolution (see Figure 8 and Table 1). The asymmetric unit for the SC0332- $\mathrm{Ca}^{2+}-\mathrm{S} 100 \mathrm{~B}$ structure included one monomer of S100B containing 88 residues (Met- 0 to Phe-87), two calcium ions, two SC0833 molecules, and 71 water molecules. The global fold and $\mathrm{Ca}^{2+}$ ion coordination of $\mathrm{S} 100 \mathrm{~B}$ in the SC0322$\mathrm{Ca}^{2+}-\mathrm{S} 100 \mathrm{~B}$ complex were very similar to that reported previously for $\mathrm{Ca}^{2+}-\mathrm{S} 100 \mathrm{~B} .{ }^{42,58}$ Specifically, each subunit of S100B in the SC0322-Ca ${ }^{2+}-\mathrm{S} 100 \mathrm{~B}$ complex contained four helices (helix 1, E2-G19; helix 2, K28-L40; helix 3, E49-D61; helix $4, \mathrm{D} 69-\mathrm{F} 88$ ) and one small antiparallel $\beta$-sheet (strand 1 , K26-K28; strand 2, D69-E67). The two EF-hand $\mathrm{Ca}^{2+}$-binding

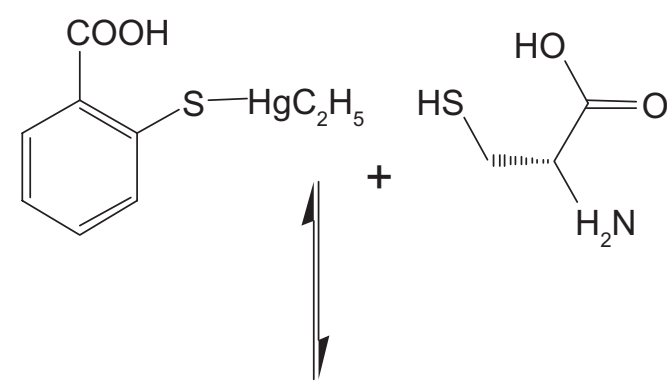<smiles>CCCSC[C@H](CN)C(=O)O</smiles>

Figure 9 Mechanism of covalent modification of cysteine by thimerosal (SC0322), resulting in the formation of ethylmercury adducts while releasing thiosalicylic acid. ${ }^{63}$

domains in each subunit were found to coordinate two $\mathrm{Ca}^{2+}$ ions as found previously with the typical EF-hand of S100B in the $\mathrm{Ca}^{2+}$-bound "open" conformation and the dimer interface aligned as a symmetric X-type four helix bundle comprising helices $1,1^{\prime}$ and 4, 4', respectively. ${ }^{27,55-58}$

Thimerosal (SC0332) is known to covalently modify cysteine residues in proteins forming ethylmercury adducts and releasing thiosalicylic acid (see Figure 9), so it was no surprise that one of the two cysteines in S100B, Cys84, was covalently modified.$^{63}$ However, visual inspection of the $2 \mathrm{mF}_{\mathrm{o}}-\mathrm{DF}_{\mathrm{c}}$ and $\mathrm{mF}_{\mathrm{o}}-\mathrm{DF}_{\mathrm{c}}$ electron density maps show that in addition to the ethylmercury adduct on Cys84, the thiosalicylic acid moiety remained associated with S100B near helix 3 and the N-terminus of helix 4. In addition, it should be noted that the mercury atom and thiosalicylic acid moiety had to be modeled with 0.25 occupancy. With these parameters, the electron density for the two hydrolyzed products of the SC0332 molecule were well defined with reasonable mean B-values $\left(\AA^{2} ; \mathrm{C} 2_{1}: 32.42\right.$ and 89.86 ; $\mathrm{C} 222_{1}$ : 56.37 and 91.30 ) when compared with the average B-factor for all protein atoms $\left(\mathrm{C} 2_{1}: 38.92 ; \mathrm{C} 222_{1}: 48.48\right.$; see Table 1$)$. Nearly all of the residues of S100B (94.0\%) in the SC0332$\mathrm{Ca}^{2+}-\mathrm{S} 100 \mathrm{~B}$ complex were in the most favorable region of the Ramachandran plot with the remaining $6.0 \%$ of the residues in the allowed region (see Table 1). The thiosalicylic acid was oriented in the hydrophobic pocket adjacent to a p53 peptidebinding site as described previously (see Figure 1). ${ }^{64,65}$ The ring interacted with several hydrophobic residues on the helix 3 (V56, T59, and L60) and helix 4 (F76, M79, and I80).

Due to the interaction seen in the X-ray crystal structure, thiosalicylic acid alone was next tested for its ability to bind 
S100B. While it did not significantly inhibit the binding of TAMRA-TRTK in the FPCA even at $2.5 \mathrm{mM}$, it did cause significant chemical shift perturbations of the HSQC NMR spectra in the fast-exchange regime. The addition of $1 \mathrm{mM}$ thiosalicylic acid to $100 \mu \mathrm{M} \mathrm{S100B}$ caused shifts in the end of helix 2 into the hinge region (N38, L40, S41), a flexible loop between helix 2 and 3, helix 3 (V56 and L60), and helix 4 (A75, F76, V77, S78, M79, T81, T82, A83) in amino acids consistent with the position of the thiosalicylic acid moiety in the SC0332-Ca ${ }^{2+}-\mathrm{S} 100 \mathrm{~B}$ X-ray crystal structure.

\section{Structural studies of the sanguinarine- $\mathrm{Ca}^{2+}-\mathrm{SIOOB}$ complex}

The X-ray structure of SC0844 bound to $\mathrm{Ca}^{2+}-\mathrm{S} 100 \mathrm{~B}$ was solved at $1.85 \AA$ (see Figure 10 and Table 1). The asymmetric unit for the SC0844-Ca ${ }^{2+}-\mathrm{S} 100 \mathrm{~B}$ structure included the biologic homodimer each consisting of 90 residues per

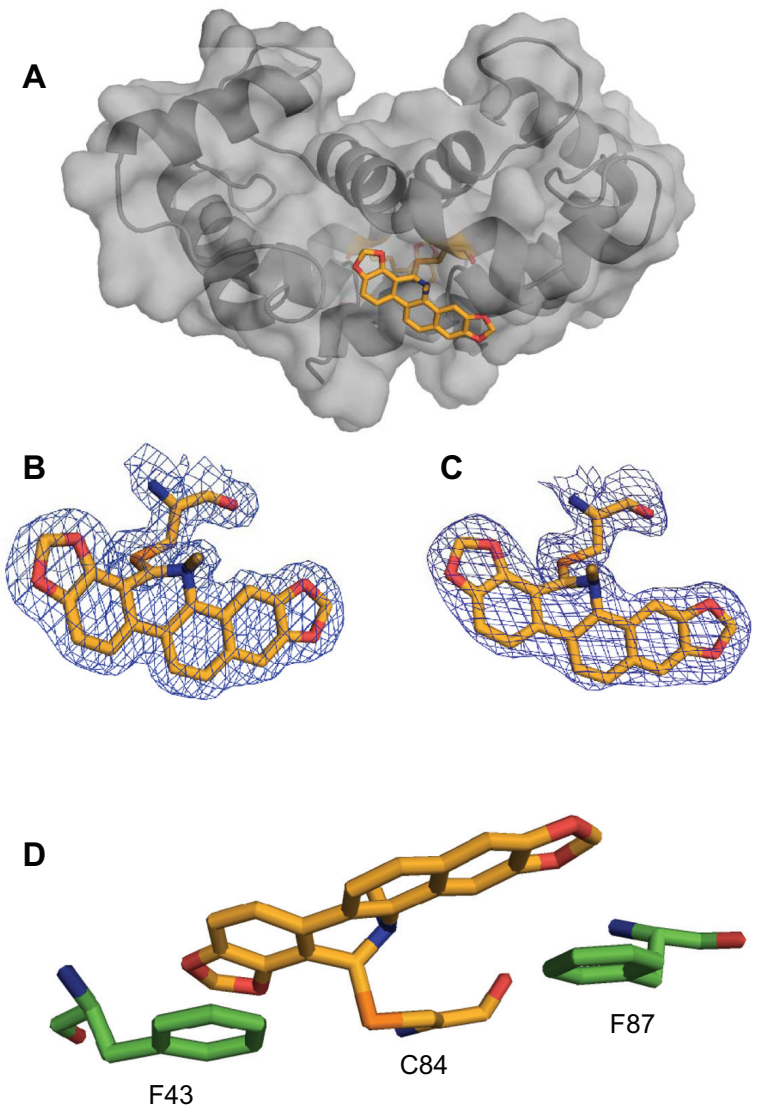

Figure 10 The X-ray structure of the SC0844-Ca ${ }^{2+}-\mathrm{SI}$ 00B complex. A) Ribbon and surface diagram of sanguinarine (SC0844)- $\mathrm{Ca}^{2+}-\mathrm{SIOOB}$, illustrating the location of SC0844 (SC0844, orange; nitrogen, blue; oxygen, red; sulfur, orange) covalently bound to Cys84. B and C) The electron density maps calculated with the $2 \mathrm{mF}_{\text {。- }}$ $D_{c}$ coefficients $(I .0 \sigma)$ for SC0833 in each monomer of the biological dimer. D) Residues in $\mathrm{Ca}^{2+}-\mathrm{SIOOB}$ involved in coordinating SC0844. (Protein Databank accession number: 3LLE). monomer (Met-0 to Glu-89), four calcium ions (two per monomer), one SC0844 molecule, and 19 water molecules (see Figure 10 and Table 1). It was evident from visual inspection of the electron density maps calculated with $2 \mathrm{mF}_{\mathrm{o}}-\mathrm{DF}_{\mathrm{c}}$ and $\mathrm{mF}_{\mathrm{o}}-\mathrm{DF}_{\mathrm{c}}$ coefficients that the only way to model SC0844 accurately was to link the molecule to Cys 84 covalently. The covalent modification of Cys 84 by SC 0844 observed here was not surprising based on previous observations that cysteine residues in proteins are modified by a structurally related compound, chelerythrine (see Figure 11). ${ }^{66}$ The SC0844 molecule was found adjacent to the crystallographic two-fold<smiles></smiles>

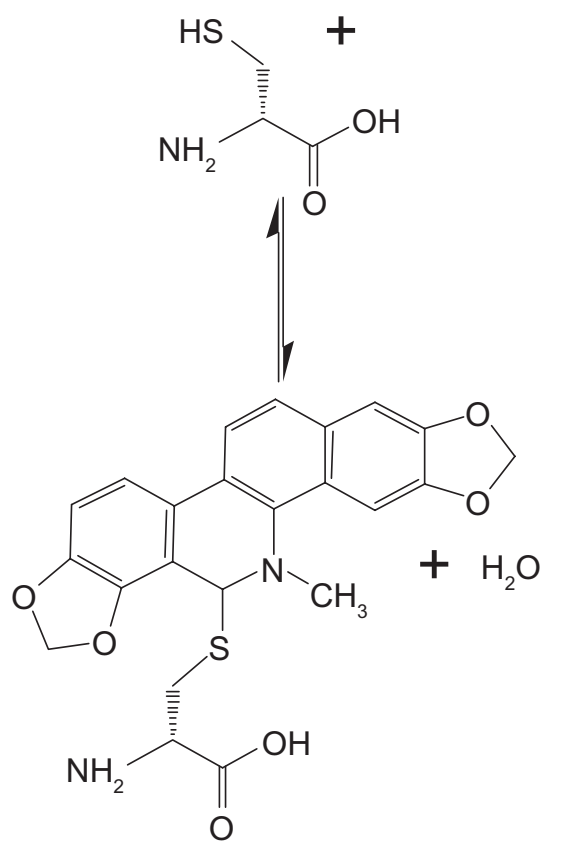

Figure II Mechanism of covalent modification of cysteine by sanguinarine (SC0844) based on the modification of cysteines in proteins by the related compound chelerythrine. ${ }^{66}$ 
axis and modeled with an occupancy of 1.0. Thus, the interactions between SC0844 and each S100B dimer were identical across the two-fold axis. Furthermore, the electron density for SC0844 was well defined (see Figure 10) with reasonable mean B-values ( $\left.\AA^{2} ; 33.62\right)$, which were comparable with the average B-factor for all protein atoms (33.61; see Table 1). Modeling SC0844 into the electron density maps calculated with $2 \mathrm{mF}_{\mathrm{o}}-\mathrm{DF}_{\mathrm{c}}$ and $\mathrm{mF}_{\mathrm{o}}-\mathrm{DF}_{\mathrm{c}}$ coefficients showed that the SC0844 molecule was oriented in the hydrophobic pocket of $\mathrm{Ca}^{2+}-\mathrm{S} 100 \mathrm{~B}$ covalently linked to Cys84, with the five rings lying flat across the hydrophobic pocket. Other than the covalent link with Cys84, the other two major interactions are ring stacking with Phe-43 from the flexible hinge region connecting helix 2 and helix 3, and with Phe87 from the C-terminal region on helix 4. Surprisingly, the C-terminal end of helix 4 bent approximately $45^{\circ}$ towards helix 1 of the other dimer. This conformational change was necessary for Phe-87 to ring stack with SC0844, and is the largest conformational change seen in $\mathrm{S} 100 \mathrm{~B}$ as a result of compound binding thus far. ${ }^{19,60}$

Nearly all of the residues in SC0844-Ca ${ }^{2+}-\mathrm{S} 100 \mathrm{~B}$ (95.2\%) were in the most favorable region of the Ramachandran plot, with the remaining $4.8 \%$ of the residues in the allowed region (see Table 1). While the global fold and $\mathrm{Ca}^{2+}$-ion coordination of S100B in the SC0844-Ca ${ }^{2+}-\mathrm{S} 100 \mathrm{~B}$ complex were very similar to that reported previously for $\mathrm{Ca}^{2+}-\mathrm{S} 100 \mathrm{~B}$ (see Figure 11), the binding of the compound causes a significant bend in helix 4 following residue Thr- $81 .{ }^{42,58}$ With the bend induced in helix 4, each subunit of S100B in the SC0844-Ca ${ }^{2+}-\mathrm{S} 100 \mathrm{~B}$ complex now contained five helices (helix 1, E2-G19; helix 2, K28-L40; helix 3, E49-D61; helix 4a, D69-T81; helix 4b, T82-H85) and one small antiparallel $\beta$-sheet (strand 1, K26-K28; strand 2, D69-E67). The two EF-hand calcium binding domains in each subunit were found to coordinate two $\mathrm{Ca}^{2+}$-ions as found previously with the typical EF-hand of S100B in the $\mathrm{Ca}^{2+}$-bound "open" conformation and the dimer interface aligned as a symmetric X-type four helix bundle comprising helices 1,1 ' and 4, 4', respectively. ${ }^{27,55-58}$

\section{Cysteine dependence of compound binding}

It became clear with the completion of the X-ray crystal structures of SC0332 and SC0844 that covalent modification of Cys 84 within the hydrophobic binding pocket is likely a common mechanism of the present S100B inhibitors. Therefore, the FPCA and NMR screens were repeated on the 26 compounds found to interact with S100B using a mutant of S100B, C68/84S, containing no cysteines. The C68/84S mutant S100B is properly folded, as judged by very minimal changes in its NMR HSQC spectrum, although it has a slightly decreased affinity for TAMRA-TRTK $\left(\mathrm{K}_{\mathrm{D}}\right.$ is $2.42 \pm 0.46 \mu \mathrm{M}$ versus $1.19 \pm 0.65 \mu \mathrm{M}$ for the wild type). The majority of the S100B inhibitors, 19 out of 26 , did not inhibit the binding of TAMRA-TRTK to the C68/84S mutant S100B, and these results were confirmed by NMR experiments showing the compounds no longer bound the mutant protein (see Table 2). While there are drugs in use that will covalently modify proteins, they are generally avoided due to their potential lack of specificity. However, other groups have taken the approach of creating libraries of drugs that bind to cysteine residues on purpose, even mutating their protein to contain a cysteine in order to get the structure of compound-protein complexes such as these. Such data, in any case, provide a useful starting point for building a specific inhibitor, as it will here for S100B. ${ }^{67}$

\section{Conclusion}

The FPCA developed here can be used in HTS to identify S100B inhibitors. Screening of the relatively small spectrum collection resulted in several inhibitors that were confirmed by NMR. It was important to show by an independent method that the compounds identified in the FPCA directly bind $\mathrm{Ca}^{2+}$ loaded S100B. For this purpose, NMR spectroscopy was chosen because chemical shift perturbations or chemical exchange broadening, as measured in ${ }^{1} \mathrm{H}^{-15} \mathrm{~N}$ HSQC experiments, occur for amino acid residues that directly interact with the ligand and/or as a result of more distant structural changes in the protein caused by the compound binding. ${ }^{68}$ The combination of screening methods provided 26 compounds that inhibited $\mathrm{S} 100 \mathrm{~B}$ in vitro. However, for the small collection examined here, most of the molecules that showed binding were found to modify at least one of the two cysteine residues in S100B covalently. Such molecules and the resulting three-dimensional structures determined here will be useful probes for the protein binding site that may lead to the design of better compounds, with the long-term goal of developing novel therapeutic agents for cancers such as malignant melanoma. However, compounds such as chlorpromazine (SC0067), which do not react covalently with S100B, will likely represent better leads. The fact that the binding site of chlorpromazine on $\mathrm{Ca}^{2+}-\mathrm{S} 100 \mathrm{~B}$ overlaps with those discovered for other S100B inhibitors (see Figure 7) suggests that this region of S100B represents a common "hot spot" for S100B inhibitors. ${ }^{19,60}$ 
Future studies will focus on discovering more lead compounds that inhibit $\mathrm{S} 100 \mathrm{~B}$ using the FPCA in vitro binding assay, including applying this method in combination with computer-aided drug design. The lead compounds presented here, as well as others discovered in larger screens, will then be further developed by modifying the compounds based on structure/activity relationships. It may be possible by tethering two or more lead compounds to derive a compound that binds S100B more tightly and with higher specificity.

\section{Acknowledgments}

These studies were supported by grants from the National Institutes of Health (GM58888; CA107331 to DJW) and from the American Cancer Society (CDD 107745 to DJW). The NMR spectrometers used in these studies were purchased, in part, with funds from shared instrumentation grants from the NIH (S10 RR15741 to DJW).

\section{Disclosure}

The authors report no conflict of interest in this work.

\section{References}

1. Weber DJ, Rustandi RR, Carrier F, Zimmer DB. Interaction of Dimeric S100B(bb) with the Tumor Suppressor Protein: A Model for Ca-dependent S100-target Protein Interactions. Dordrecht, The Netherlands: Kluwer Academic Publishers; 2000.

2. Harpio R, Einarsson R. S100 proteins as cancer biomarkers with focus on S100B in malignant melanoma. Clin Biochem. 2004;37(7):512-518.

3. Springall DR, Gu J, Cocchia D, et al. The value of S-100 immunostaining as a diagnostic tool in human malignant melanomas. A comparative study using S-100 and neuron-specific enolase antibodies. Virchows Arch A Pathol Anat Histopathol. 1983;400(3):331-343.

4. Baudier J, Delphin C, Grunwald D, Khochbin S, Lawrence JJ. Characterization of the tumor suppressor protein p53 as a protein kinase C substrate and a S100b-binding protein. Proc Natl Acad Sci U SA. 1992; 89(23):11627-11631.

5. Lin J, Blake M, Tang C, et al. Inhibition of $\mathrm{p} 53$ transcriptional activity by the S100B calcium-binding protein. J Biol Chem. 2001;276(37): 35037-35041.

6. Lin J, Yang Q, Yan Z, et al. Inhibiting S100B restores p53 levels in primary malignant melanoma cancer cells. J Biol Chem. 2004;279(32): 34071-34077.

7. Delphin C, Ronjat M, Deloulme JC, et al. Calcium-dependent interaction of S100B with the C-terminal domain of the tumor suppressor $\mathrm{p} 53$. J Biol Chem. 1999;274(15):10539-10544.

8. Hibi K, Fujitake S, Takase T, et al. Identification of S100A2 as a target of the DeltaNp63 oncogenic pathway. Clin Cancer Res. 2003;9(11): 4282-4285.

9. Slomnicki LP, Nawrot B, Lesniak W. S100A6 binds p53 and affects its activity. Int J Biochem Cell Biol. 2009;41(4):784-790.

10. van Dieck J, Teufel DP, Jaulent AM, et al. Posttranslational modifications affect the interaction of $\mathrm{S} 100$ proteins with tumor suppressor $\mathrm{p} 53$. J Mol Biol. 2009;394(5):922-930.

11. van Dieck J, Fernandez-Fernandez MR, Veprintsev DB, Fersht AR. Modulation of the oligomerization state of $\mathrm{p} 53$ by differential binding of proteins of the S100 family to p53 monomers and tetramers. $J$ Biol Chem. 2009;284(20):13804-13811.

12. van Dieck J, Brandt T, Teufel DP, Veprintsev DB, Joerger AC, Fersht AR. Molecular basis of S100 proteins interacting with the p53 homologs p63 and p73. Oncogene. 2010;29(14):2024-2035.
13. Chen H, Fernig DG, Rudland PS, Sparks A, Wilkinson MC, Barraclough R. Binding to intracellular targets of the metastasisinducing protein, S100A4 (p9Ka). Biochem Biophys Res Commun. 2001;286(5):1212-1217.

14. Grigorian M, Andresen S, Tulchinsky E, et al. Tumor suppressor p53 protein is a new target for the metastasis-associated Mts $1 / \mathrm{S} 100 \mathrm{~A} 4$ protein: Functional consequences of their interaction. $J$ Biol Chem. 2001;276(25):22699-22708.

15. Bogan AA, Thorn KS. Anatomy of hot spots in protein interfaces. J Mol Biol. 1998;280(1):1-9.

16. Gadek TR, Nicholas JB. Small molecule antagonists of proteins. Biochem Pharmacol. 2003;65(1):1-8.

17. Zhong S, Macias AT, MacKerell AD Jr. Computational identification of inhibitors of protein-protein interactions. Curr Top Med Chem. 2007; 7(1):63-82.

18. Wilder PT, Lin J, Bair CL, et al. Recognition of the tumor suppressor protein $\mathrm{p} 53$ and other protein targets by the calcium-binding protein S100B. Biochim Biophys Acta. 2006;1763(11):1284-1297.

19. Charpentier TH, Wilder PT, Liriano MA, et al. Small molecules bound to unique sites in the target protein binding cleft of calcium-bound $\mathrm{S} 100 \mathrm{~B}$ as characterized by nuclear magnetic resonance and x-ray crystallography. Biochemistry. 2009;48(26): $6202-6212$.

20. Rustandi RR, Drohat AC, Baldisseri DM, Wilder PT, Weber DJ. The $\mathrm{Ca}(2+)$-dependent interaction of $\mathrm{S} 100 \mathrm{~B}$ (beta beta) with a peptide derived from p53. Biochemistry. 1998;37(7):1951-1960.

21. Wilder PT, Rustandi RR, Drohat AC, Weber DJ. S100B(betabeta) inhibits the protein kinase $\mathrm{C}$-dependent phosphorylation of a peptide derived from p53 in a Ca2+-dependent manner. Protein Sci. 1998; 7(3):794-798.

22. Rustandi RR, Baldisseri DM, Weber DJ. Structure of the negative regulatory domain of $\mathrm{p} 53$ bound to $\mathrm{S} 100 \mathrm{~B}$ (betabeta). Nat Struct Biol. 2000;7(7):570-574.

23. Rustandi RR, Baldisseri DM, Drohat AC, Weber DJ. Structural changes in the C-terminus of $\mathrm{Ca} 2+-$ bound rat $\mathrm{S} 100 \mathrm{~B}$ (beta beta) upon binding to a peptide derived from the C-terminal regulatory domain of $\mathrm{p} 53$. Protein Sci. 1999;8(9):1743-1751.

24. Inman KG, Yang R, Rustandi RR, Miller KE, Baldisseri DM, Weber DJ. Solution NMR structure of S100B bound to the high-affinity target peptide TRTK-12. J Mol Biol. 2002;324(5):1003-1014.

25. Charpentier TH, Thompson LE, Liriano MA, et al. The effects of CapZ peptide (TRTK-12) binding to $\mathrm{S} 100 \mathrm{~B}-\mathrm{Ca}(2+)$ as examined by NMR and X-ray crystallography. J Mol Biol. 2010;396(5):1227-1243.

26. Huang X, Aulabaugh A. Application of fluorescence polarization in HTS assays. Methods Mol Biol. 2009;565:127-143.

27. Amburgey JC, Abildgaard F, Starich MR, Shah S, Hilt DC, Weber DJ. $1 \mathrm{H}, 13 \mathrm{C}$ and $15 \mathrm{~N} \mathrm{NMR}$ assignments and solution secondary structure of rat Apo-S100 beta. J Biomol NMR. 1995;6(2):171-179.

28. Drohat AC, Amburgey JC, Abildgaard F, Starich MR, Baldisseri D, Weber DJ. Solution structure of rat apo-S100B(beta beta) as determined by NMR spectroscopy. Biochemistry. 1996;35(36):11577-11588.

29. Konecsni T, Kilar F. Monitoring of the conjugation reaction between human serum transferrin and fluorescein isothiocyanate by capillary electrophoresis. J Chromatogr A. 2004;1051(1-2):135-139.

30. Zhang JH, Chung TD, Oldenburg KR. A simple statistical parameter for use in evaluation and validation of high throughput screening assays. J Biomol Screen. 1999;4(2):67-73.

31. Nikolovska-Coleska Z, Wang R, Fang X, et al. Development and optimization of a binding assay for the XIAP BIR3 domain using fluorescence polarization. Anal Biochem. 2004;332(2): 261-273.

32. Marion D, Driscoll PC, Kay LE, et al. Overcoming the overlap problem in the assignment of $1 \mathrm{H}$ NMR spectra of larger proteins by use of three-dimensional heteronuclear $1 \mathrm{H}-15 \mathrm{~N}$ Hartmann-Hahn-multiple quantum coherence and nuclear Overhauser-multiple quantum coherence spectroscopy: Application to interleukin 1 beta. Biochemistry. 1989;28(15):6150-6156. 
33. Bax A, Ikura M. An efficient 3D NMR technique for correlating the proton and $15 \mathrm{~N}$ backbone amide resonances with the alpha-carbon of the preceding residue in uniformly $15 \mathrm{~N} / 13 \mathrm{C}$ enriched proteins. $J$ Biomol NMR. 1991;1(1):99-104.

34. Delaglio F, Grzesiek S, Vuister GW, Zhu G, Pfeifer J, Bax A. NMRPipe: A multidimensional spectral processing system based on UNIX pipes. J Biomol NMR. 1995;6(3):277-293.

35. Edison AS, Abildgaard F, Westler WM, Mooberry ES, Markley JL. Practical introduction to theory and implementation of multinuclear, multidimensional nuclear magnetic resonance experiments. Methods Enzymol. 1994;239:3-79.

36. Live DH, Davis DG, Agosta WC, Cowburn D. J Am Chem Soc. 1984(106):1939-1941.

37. Spera S, Ikura M, Bax A. Measurement of the exchange rates of rapidly exchanging amide protons: Application to the study of calmodulin and 1991;1(2):155-165.

38. Mori S, Abeygunawardana C, Johnson MO, van Zijl PC. Improved sensitivity of HSQC spectra of exchanging protons at short interscan delays using a new fast HSQC (FHSQC) detection scheme that avoids water saturation. J Magn Reson B. 1995;108(1):94-98.

39. Mayer M, Meyer B. Group epitope mapping by saturation transfer difference NMR to identify segments of a ligand in direct contact with a protein receptor. J Am Chem Soc. 2001;123(25):6108-6117.

40. Bax A, Davis DG. Practical aspects of two-dimensional transverse NOE spectroscopy. Journal of Magnetic Resonance. 1985;63:207-213.

41. Otwinowski Z, Minor W. Processing of X-ray diffraction data collected in oscillation mode. Methods Enzymol. 1997;276:307-326.

42. Matsumura H, Shiba T, Inoue T, Harada S, Kai Y. A novel mode of target recognition suggested by the 2.0 A structure of holo S100B from bovine brain. Structure. 1998;6(2):233-241.

43. Vagin AA, Isupov MN. Spherically averaged phased translation function and its application to the search for molecules and fragments in electrondensity maps. Acta Crystallogr D Biol Crystallogr. 2001;57(Pt 10): 1451-1456.

44. Murshudov GN, Vagin AA, Dodson EJ. Refinement of macromolecular structures by the maximum-likelihood method. Acta Crystallogr D Biol Crystallogr. 1997;53(Pt 3):240-255.

45. Emsley P, Cowtan K. Coot: Model-building tools for molecular graphics. Acta Crystallogr D Biol Crystallogr. 2004;60(Pt 12 Pt 1): 2126-2132.

46. Laskowski RA, MacArthur MW, Moss DS, Thornton JM. PROCHECK: A program to check the stereochemical quality of protein structures. J Appl Crystallogr. 1993;26(2):283-291.

47. Laskowski RA, MacArthur MW, Thornton JM. Validation of protein models derived from experiment. Curr Opin Struct Biol. 1998;8(5):631-639.

48. Berman HM, Westbrook J, Feng Z, et al. The protein data bank. Nucleic Acids Res. 2000;28(1):235-242.

49. Yang H, Guranovic V, Dutta S, Feng Z, Berman HM, Westbrook JD. Automated and accurate deposition of structures solved by X-ray diffraction to the Protein Data Bank. Acta Crystallogr D Biol Crystallogr. 2004;60(Pt 10):1833-1839.

50. Danley DE. Crystallization to obtain protein-ligand complexes for structure-aided drug design. Acta Crystallogr D Biol Crystallogr. 2006;62(Pt 6):569-575. its complex with a myosin light chain kinase fragment. J Biomol NMR.

51. Feng BY, Shelat A, Doman TN, Guy RK, Shoichet BK. High-throughput assays for promiscuous inhibitors. Nat Chem Biol. 2005;1(3): $146-148$

52. McGovern SL, Caselli E, Grigorieff N, Shoichet BK. A common mechanism underlying promiscuous inhibitors from virtual and highthroughput screening. J Med Chem. 2002;45(8):1712-1722.

53. Ou B, Hampsch-Woodill M, Prior RL. Development and validation of an improved oxygen radical absorbance capacity assay using fluorescein as the fluorescent probe. J Agric Food Chem. 2001;49(10):4619-4626.

54. Huang X. Fluorescence polarization competition assay: The range of resolvable inhibitor potency is limited by the affinity of the fluorescent ligand. J Biomol Screen. 2003;8(1):34-38.

55. Baudier J, Glasser N, Gerard D. Ions binding to S100 proteins. I. Calcium- and zinc-binding properties of bovine brain S100 alpha alpha, $\mathrm{S} 100 \mathrm{a}$ (alpha beta), and S100b (beta beta) protein: $\mathrm{Zn} 2+$ regulates $\mathrm{Ca} 2+$ binding on S100b protein. J Biol Chem. 1986;261(18):8192-8203.

56. Kligman D, Hilt DC. The S100 protein family. Trends Biochem Sci. 1988;13(11):437-443.

57. Strynadka NC, James MN. Crystal structures of the helix-loop-helix calcium-binding proteins. Annu Rev Biochem. 1989;58:951-998.

58. Drohat AC, Baldisseri DM, Rustandi RR, Weber DJ. Solution structure of calcium-bound rat $\mathrm{S} 100 \mathrm{~B}$ as determined by nuclear magnetic resonance spectroscopy. Biochemistry. 1998;37(9):2729-2740.

59. Wilder PT, Varney KM, Weiss MB, Gitti RK, Weber DJ. Solution structure of zinc- and calcium-bound rat S100B as determined by nuclear magnetic resonance spectroscopy. Biochemistry. 2005;44(15): 5690-5702.

60. Charpentier TH, Wilder PT, Liriano MA, et al. Divalent metal ion complexes of S100B in the absence and presence of pentamidine. J Mol Biol. 2008;382(1):56-73.

61. Santamaria-Kisiel L, Rintala-Dempsey AC, Shaw GS. Calciumdependent and -independent interactions of the S100 protein family. Biochem J. 2006;396(2):201-214.

62. Weber DJ, Rustandi RR, Carrier F, Zimmer DB. Interaction of Dimeric S100B (bb) with the Tumor Suppressor Protein: A Model for Ca-dependent S100-target Protein Interactions. Dordrecht, The Netherlands: Kluwer Academic Publishers; 2000.

63. Wu X, Liang H, O’Hara KA, Yalowich JC, Hasinoff BB. Thiolmodulated mechanisms of the cytotoxicity of thimerosal and inhibition of DNA topoisomerase II alpha. Chem Res Toxicol. 2008;21(2): 483-493.

64. Rustandi RR, Baldisseri DM, Weber DJ. Structure of the negative regulatory domain of p53 bound to S100B. Nat Struct Biol. 2000;7(7): 570-574.

65. Markowitz J, Chen I, Gitti R, et al. Identification and characterization of small molecule inhibitors of the calcium-dependent S100B-p53 tumor suppressor interaction. J Med Chem. 2004;47:5085-5093.

66. Lou H, Ookhtens M, Stolz A, Kaplowitz N. Chelerythrine stimulates GSH transport by rat Mrp2 (Abcc2) expressed in canine kidney cells. Am J Physiol Gastrointest Liver Physiol. 2003;285(6):G1335-G1344.

67. Erlanson DA, Braisted AC, Raphael DR, et al. Site-directed ligand discovery. Proc Natl Acad Sci U S A . 2000;97(17):9367-9372.

68. Zuiderweg ER. Mapping protein-protein interactions in solution by NMR spectroscopy. Biochemistry. 2002;41(1):1-7.

International Journal of High Throughput Screening

\section{Publish your work in this journal}

International Journal of High Throughput Screening is an international, peer-reviewed, open access journal publishing original research, reports, editorials, reviews and commentaries dedicated to all aspects of high throughput screening, especially related to drug discovery and associated areas of biology and chemistry. The manuscript management sys-

Submit your manuscript here: http://www.dovepress.com/international-journal-of-high-throughput-screening-journal

\section{Dovepress}

tem is completely online and includes a very quick and fair peer-review system. Visit http://www.dovepress.com/testimonials.php to read real quotes from published authors. 